\title{
ANALISIS KESTABILAN LERENG DENGAN SOFTWARE ROCSCIENCE SLIDE
}

\author{
Darmadi.Ir dan Atiyya Inayatillah
}

\begin{abstract}
Abstrak
Analisis kestabilan lereng dengan SOFTWARE ROCSCIENCE SLIDE studi kasus di barak pemukiman PT. Freport dengan berbagai variasi pembebanan dan kondisi menunjukan hasil Semakin besar beban yang ada pada lereng maka maka nilai Factor of Safety semakin kecil. Nilai FS untuk semua metode, section, dan lebar ramp lebih besar dalam kondisi kering daripada basah. Semakin besar jarak beban dari lereng maka maka nilai FS semakin besar. Pada jarak $3 m$ dari crest lereng penurunan nilai FS sangat sifnifikan, pada section 1 dan 2 masih didapatkan niali FS yang aman dengan beban 50 kN/m, Semakin kecil sudut lereng keseluruhan (landai) maka nilai FS semakin besar.
\end{abstract}

Kata kunci : Kestabilan lereng, faktor keamanan,beban maksimum

\section{Latar Belakang}

Konsdisi existing barrack yang akan di bangun di depan FSC terletak di puncak lereng dengan sudut kemiringan sekitar $45^{\circ}$ dan ketinggian maximum 13 meter. Karena lokasi pembangunan barrack baru merupakan lereng yang curam dengan sudut kemiringan yang cukup besar, maka diperlukan analisis kestabilan lereng untuk mengetahui apakah lokasi tersebut cukup aman atau tidak.

Beban bangunan atau beban luar yang bekerja relatif dekat dengan crest lereng akan menyebabkan arah pergerakan tanah bergerak dari dasar pondasi langsung menuju lereng bagian bawah dan memberikan tambahan beban gravitasi yang menyebabkan turunnya stabilitas lereng.

Dalam analisis ini akan dicoba untuk menganalisis kestabilan lereng dengan berbagai variasi beban, sehingga didapatkan beban maksimum yang dapat ditahan oleh lereng. Karena desain barrack belum ada maka digunakan range beban terbagi rata untuk analisis daya dukung tanah dan kestabilan lereng. Geometri lereng dimodelkan dengan komputer sehingga bisa dianalisis factor of safety (FoS) dan daya dukung tanah berdasarkan parameter geoteknik yang ada dan metode yang digunakan. Analisis akan dilakukan dalam dua kondisi yaitu kondisi kering dan basah (saturated), sehingga didapatkan beban maksimal yang dapat ditahan oleh lereng dengan nilai FoS yang cukup aman baik pada kondisi kering maupun basah (saturated).

\section{Langkah Analisis Kestabilan Lereng dengan Software Rocscience Slide}

Sebelum masuk ke Rocscience Slide geometri desain harus dibuat di AotoCAD dan disimpan dalam format $d x f$. Beberapa geometri desain harus dibuat di AutoCAD karena memodifikasi desain di Slide tidak selengkap dengan AutoCAD yang memang mempunyai spesifikasi sebagai drawing software.

Berikut ini adalah metodologi penelitian untuk analisis kestabilan lereng menggunakan Rocscience Slide sesuai dengan cara kerja software tersebut. 


\section{Pemodelan}

Pemodelan geometri lereng yang akan dianalisis bisa dilakukan langsung di Rocscience Slide. Tetapi untuk memenuhi geometri sesuai dengan kondisi asli cara ini kurang teliti. Untuk itu pemodelan dilakukan dengan software lain. Dalam Skripsi ini pemodelan dilakukan dengan mengambil data topografi lereng didepan FSC area yang terbaru dan dimasukkan ke dalam software AutoCad. Untuk mempermudah menganalisis kestabilan lereng, maka data topografi dibagi menjadi 3 section. Selanjutnya section tersebut dimodifikasi dengan AutoCAD sesuai dengan geometri desain yang diinginkan. Section yang akan disajikan ke Rocscience Slide juga bisa dipersempit hanya pada bagian yang akan dianilisis.

Setelah geometri siap selanjutnya adalah memasukkan geometri tersebut ke Rocscience Slide. Setelah aplikasi Rocscience Slide dibuka langkah pertama adalah membuat nama file baru. Kemudian mengambil gambar dalam format $d x f$ melalui langkah file-import-importdxf. Pertama kali kita harus mengimpor external boundary atau batas paling luar dari section yang dianalisis. Setelah itu impor material boundary. Dalam sebuah lereng bisa terdapat beberapa jenis material. Material boundary adalah batas antar material tersebut.
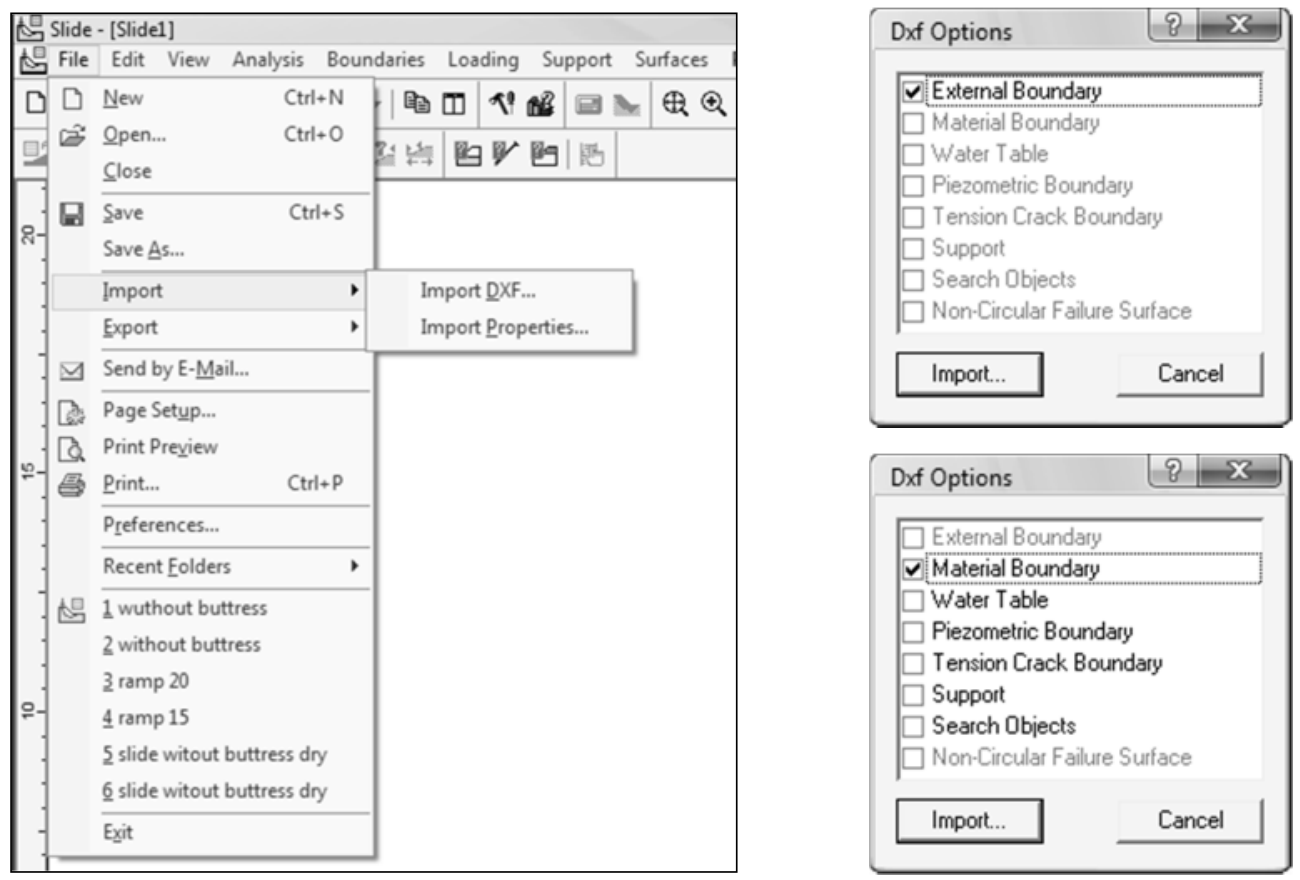

Gambar 1. Langkah untuk mengimpor external boundary dan material boundary

Tampilan setelah external boundary dan material boundary diimpor dapat dilihat pada gambar 4 dan 5 


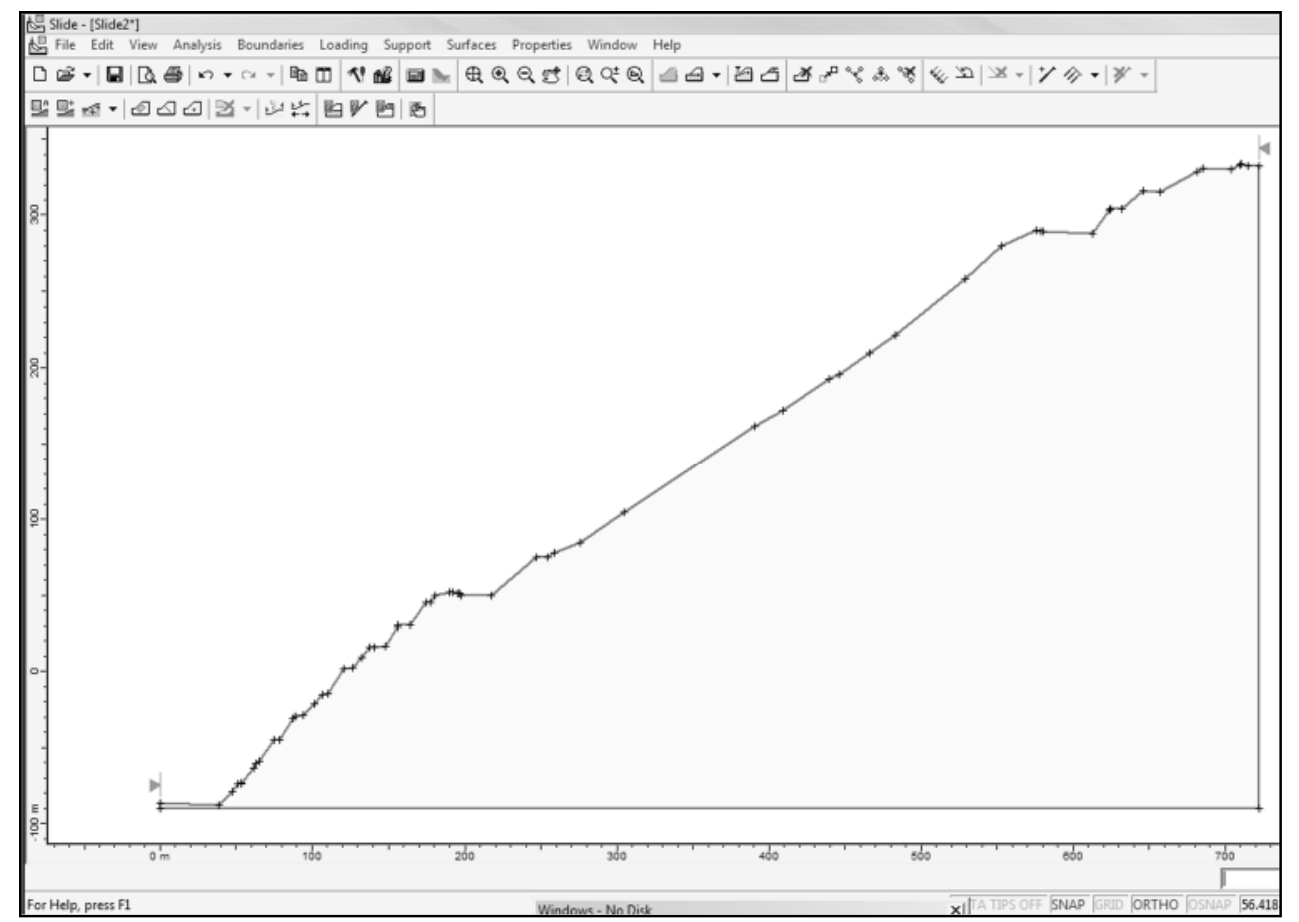

Gambar 4. Geometri external boundary setelah diimpor ke Slide

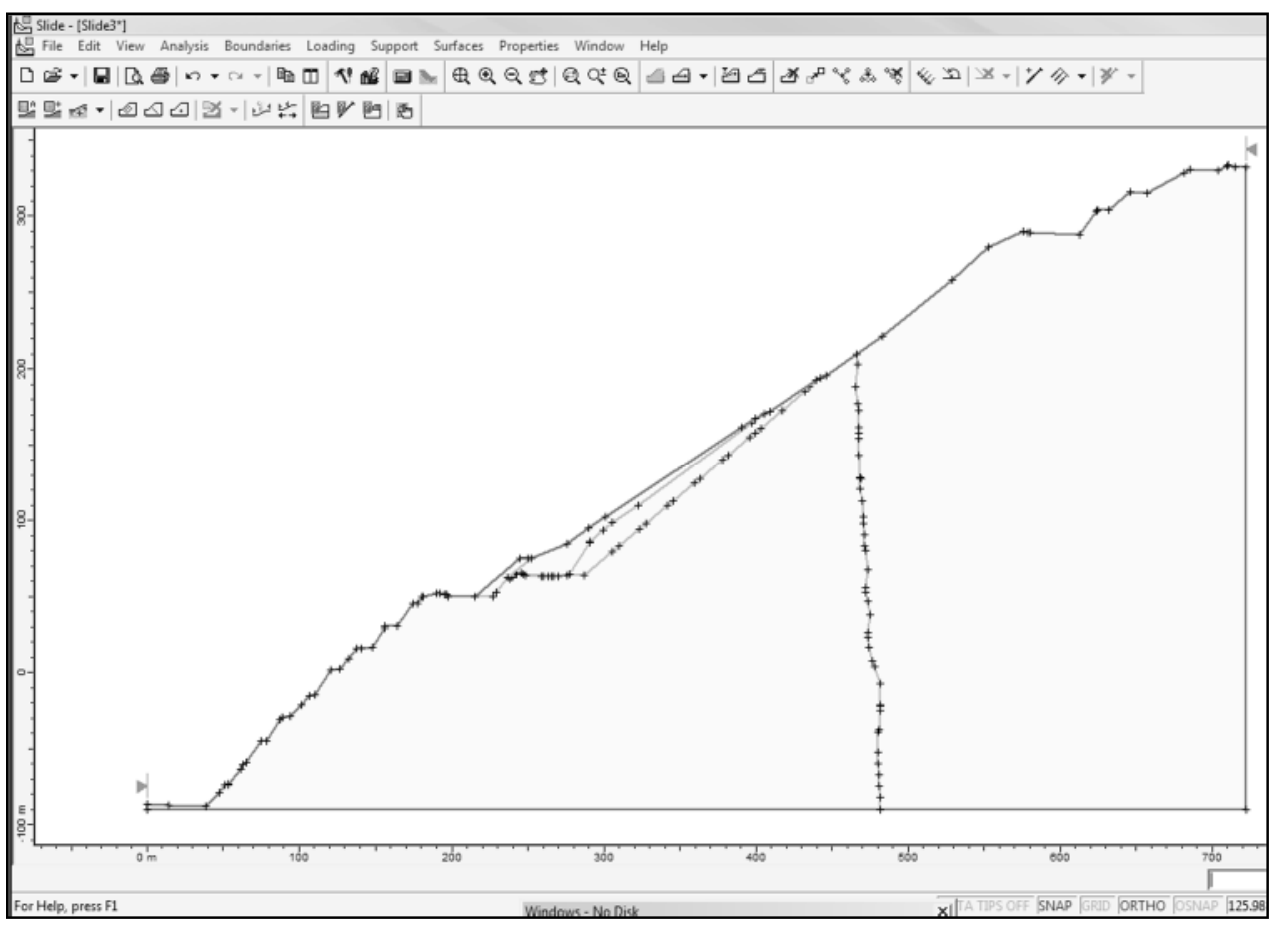

Gambar 5. Geometri material boundary setelah diimpor ke Slide

\section{Identifikasi Metode dan Parameter Perhitungan}

Dalam analisis kestabilan lereng terdapat beragam metode dengan parameter yang berbeda. Metode dan parameter perhitungan tersebut harus diidentifikasikan dengan tepat. 
Langkah pertama untuk menentukan metode perhitungan adalah klik menu Analysis-Project Settings seperti pada gambar 3.12.

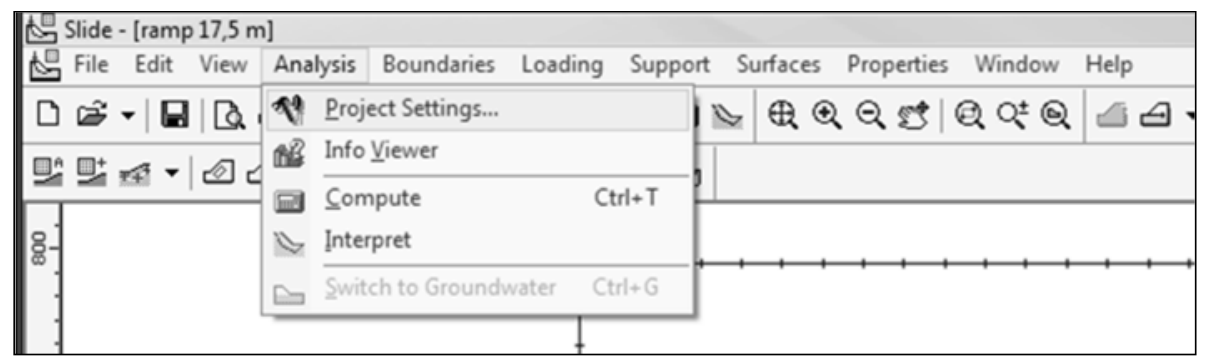

Gambar 6. Geometri material boundary setelah diimpor ke Slide

Setelah itu akan muncul top up mеnu seperti pada gambar 7 hingga 9. Project setting terdiri dari beberapa bagian yaitu General, Methods, Groundwater, Statistics, dan Random Numbers. Generaladalah pengaturan umum tentang judul, satuan, arah longsoran, dan beberapa data penunjang.

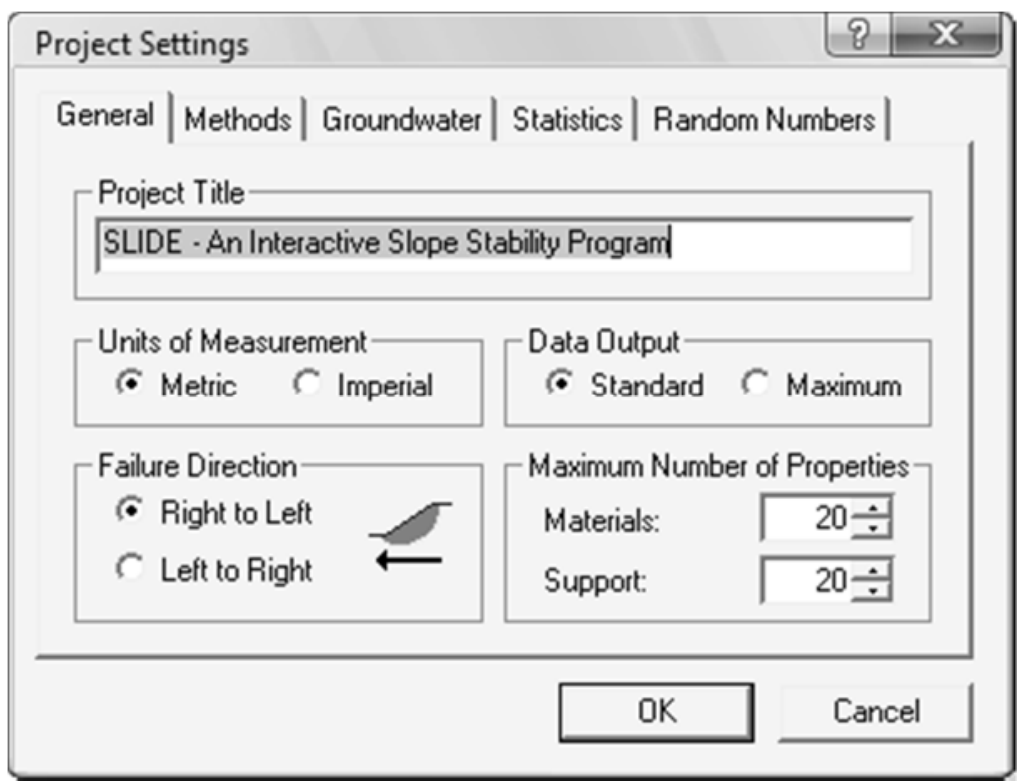

Gambar 7. Pengaturan umum dalam Project Settings

Methods adalah pengaturan metode perhitungan yang digunakan. Dalam Skripsi ini metode yang digunakan adalah Bishop simplified dan Ordinary/Fellenius. Metode yang akan digunakan dapat dipilih lebih dari satu dan masing-masing metode dapat dinterpretasikan dengan software komplemen Rocscience Slide yaitu Rocscience Slide Interpret. Pada kolom Converage Options terdapat pilihan jumlah slice/irisan dalam perhitungan FoS. Jumlah irisan yang digunakan sebanyak 25. Sedangkan Tolerance dan Maximum Number of Iterations adalah alat bantusampling statistik untuk menentukan kemungkinan yang tidak pasti dalam perhitungan.

Groundwater adalah pengaturan tentang pengaruh air di dalam kestabilan lereng. Setiap groundwater method akan meminta parameter yang berbeda. Dalam Tugas Akhir ini groundwater method digunakan nilai Rucoefficient 
dengan asumsi kondisi kering dan jenuh sempurna (fullysaturated). Nilai Rucoefficient tersebut akan dimasukkan ke dalam material properties.

Dua kolom terakhir pada bagian kanan adalah Statistic dan Random Numbers.Menu ini tidak harus dipilih (bisa dikosongkan).Statistics berisi pilihan tentang metode sampling yang digunakan dan parameter yang menyertainya yang harus dimasukkan pada Random Numbers.

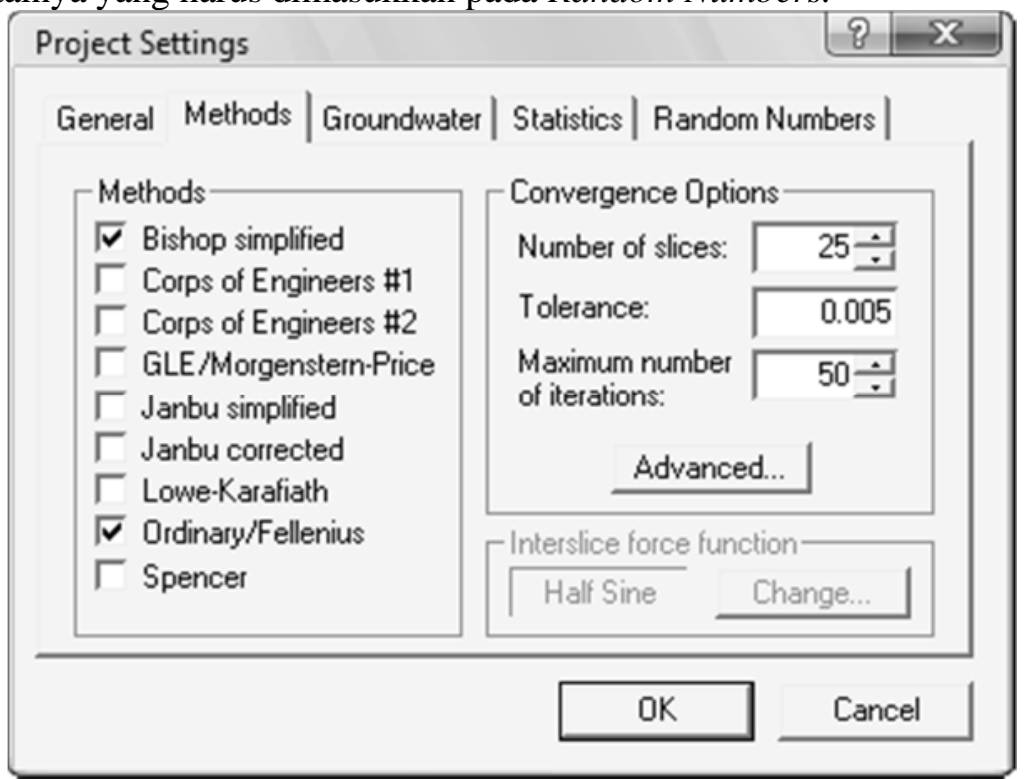

Gambar 8. Pengaturan metode yang digunakan

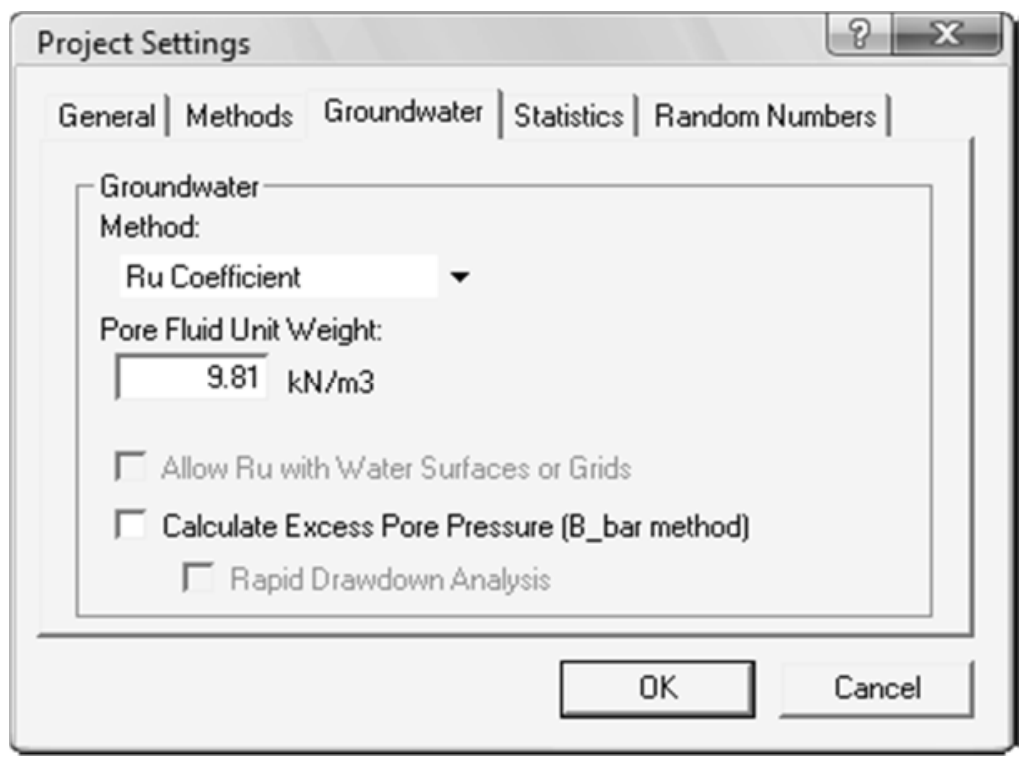

Gambar 9. Pengaturan pengaruh air dalam kestabilan lereng

\section{Identifikasi Material}

Material pembentuk lereng yang akan dianalisis harus dimasukkan ke dalam data Rocscience Slide. Langkah untuk mengatur material adalah klik Menu Properties-Define Materials. 


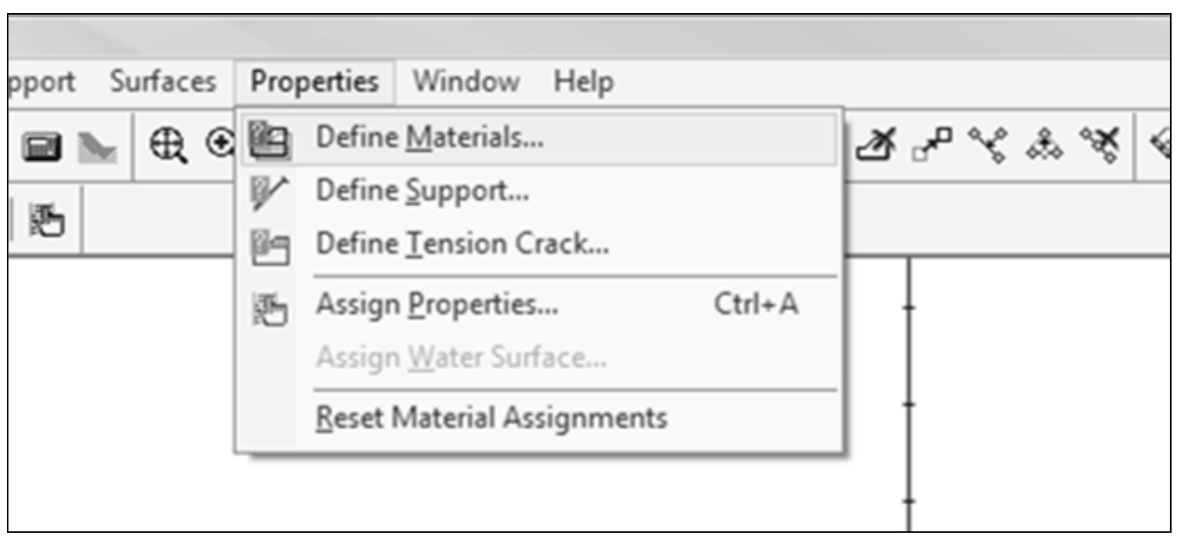

Gambar 10. Langkah untuk membuka menu pengaturan material

Setelah itu akan muncul рор ир тепи pengaturan material. Setiap material bisa diatur nama dan warnanya untuk memudahkan dalam penyajian. Karekteristik pertama yang harus dimasukkan adalah bobot isi/unit weight. Setelah itu pilih jenis analisis kekuatan. Setiap jenis akan meminta parameter yang berbeda. Misalnya jika digunakan Mohr-Coulomb maka parameter yang harus dilengkapi adalah kohesi dan sudut geser dalam. Sedangkan water parameters berupa nilai $R u$ hanya akan muncul jika dalam groundwater method digunakan $R u$ coefficient.

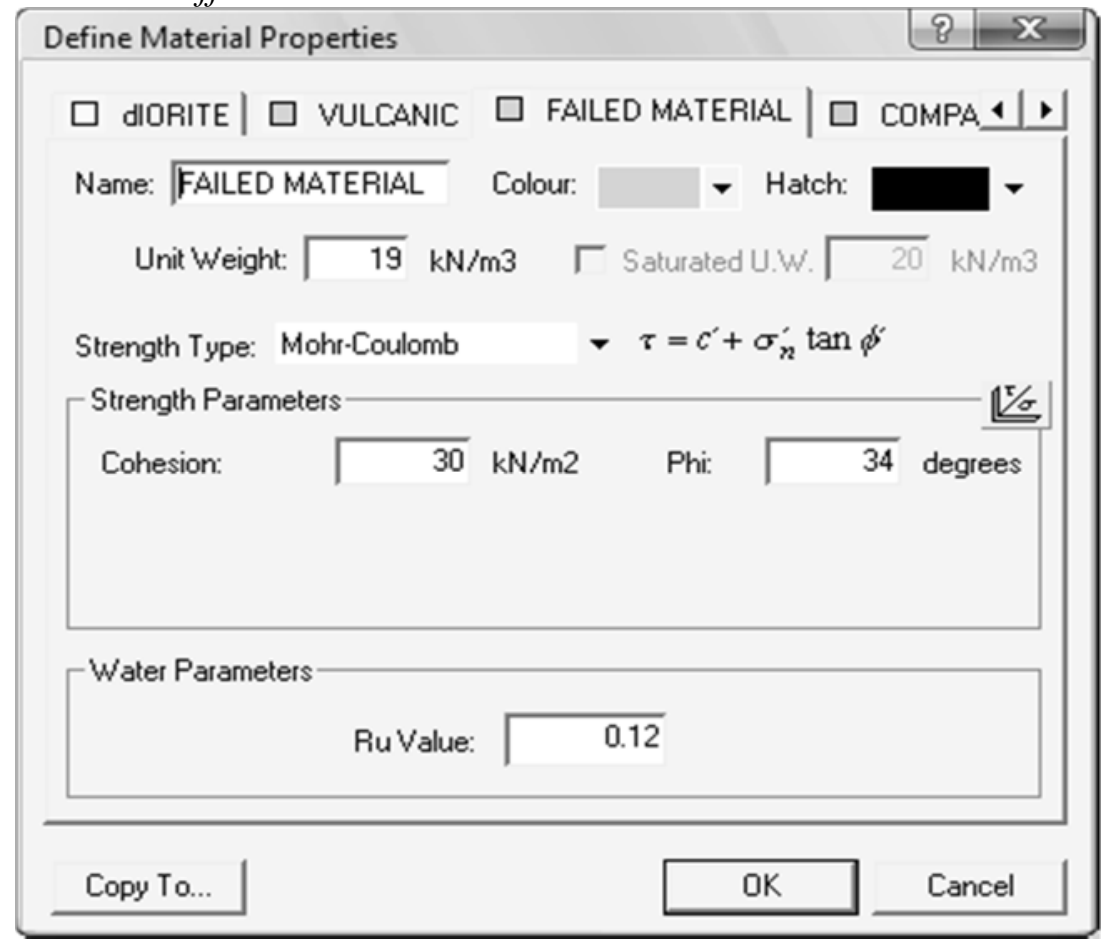

Gambar 11. Langkah untuk membuka menu pengaturan material

Langkah selanjutnya adalah menempatkan material pada gambar berdasarkan material boundary dengan karakteristik yang telah dibuat. Tampilan lereng akan berubah dengan warna sesuai materialnya seperti pada gambar. 


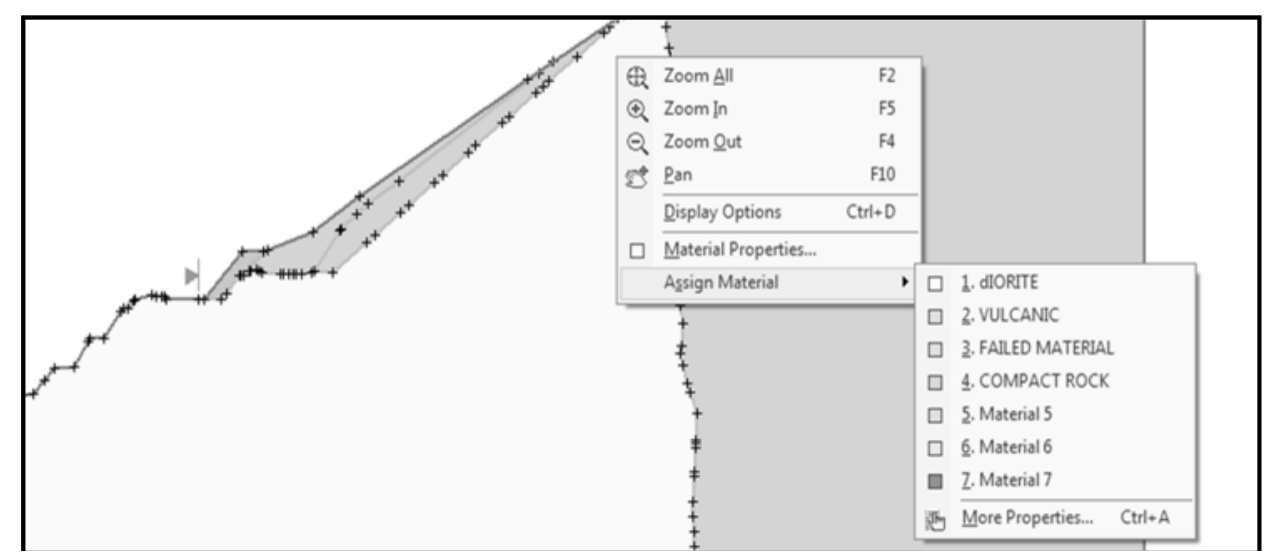

Gambar 12. Assignmaterial pada lereng

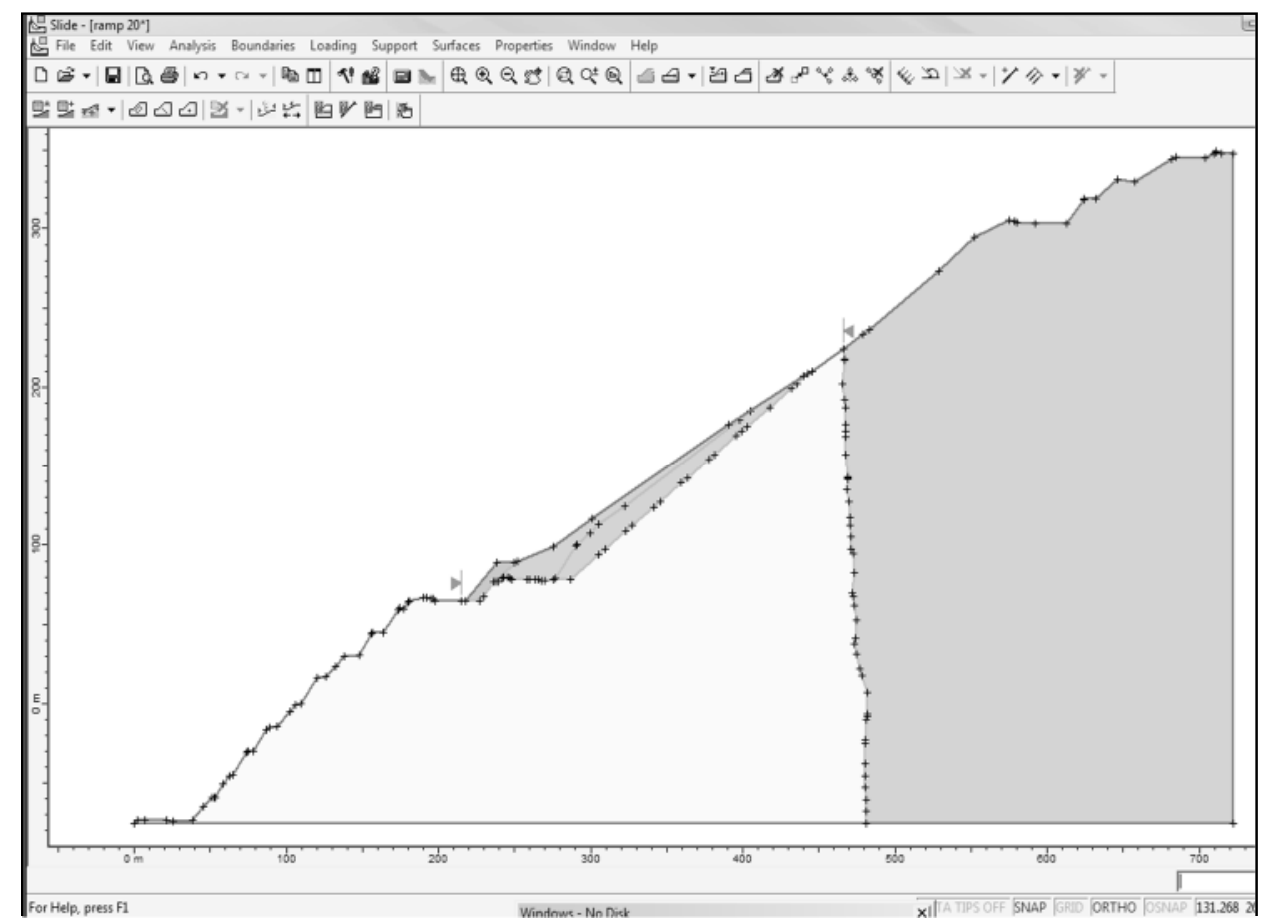

Gambar 13. Setiap jenis material diwakili oleh warna yang berbeda

\section{Penentuan Bidang Gelincir}

Kemungkinan bidang gelincir yang akan terjadi pada lereng yang dianalisis dapat dipilih dengan klik menu Surfaces-Surfece Options kemudian akan muncul top up mепи seperti pada gambar 17. Penentuan bidang gelincir disesuaikan dengan kemungkinan bidang longsor pada lereng yang akan dianalisis. Untuk lereng ini digunakan bidang gelincir berbentuk lingkaran karena merupakan material padatan yang homogen. 


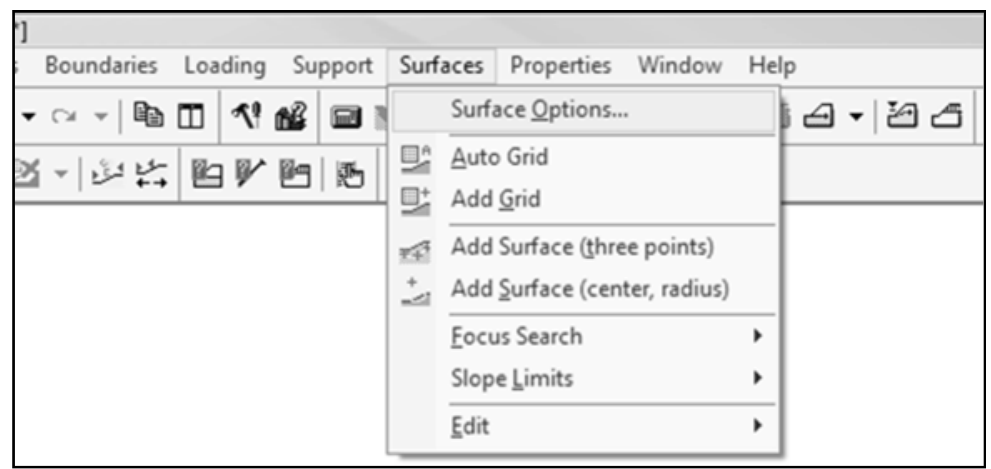

Gambar 14. Langkah untuk membuka pengaturan bidang gelincir

Setelah Surface Type dipilih Circular selanjutnya adalah mengatur metode pencarian kemungkinan bidang gelincir. Radius Increment menunjukkan jumlah interval antara radius terbesar dan terkecil pada setiap titik pusat gelincir. Sedangkan composite surfaces adalah bidang gelincir berbentuk busur lingkaran yang melewati lebih dari satu jenis material. Sedangkan tension crack dipilih karena kemungkinan bidang gelincir pada lereng ini hanya akan melewati filled material.

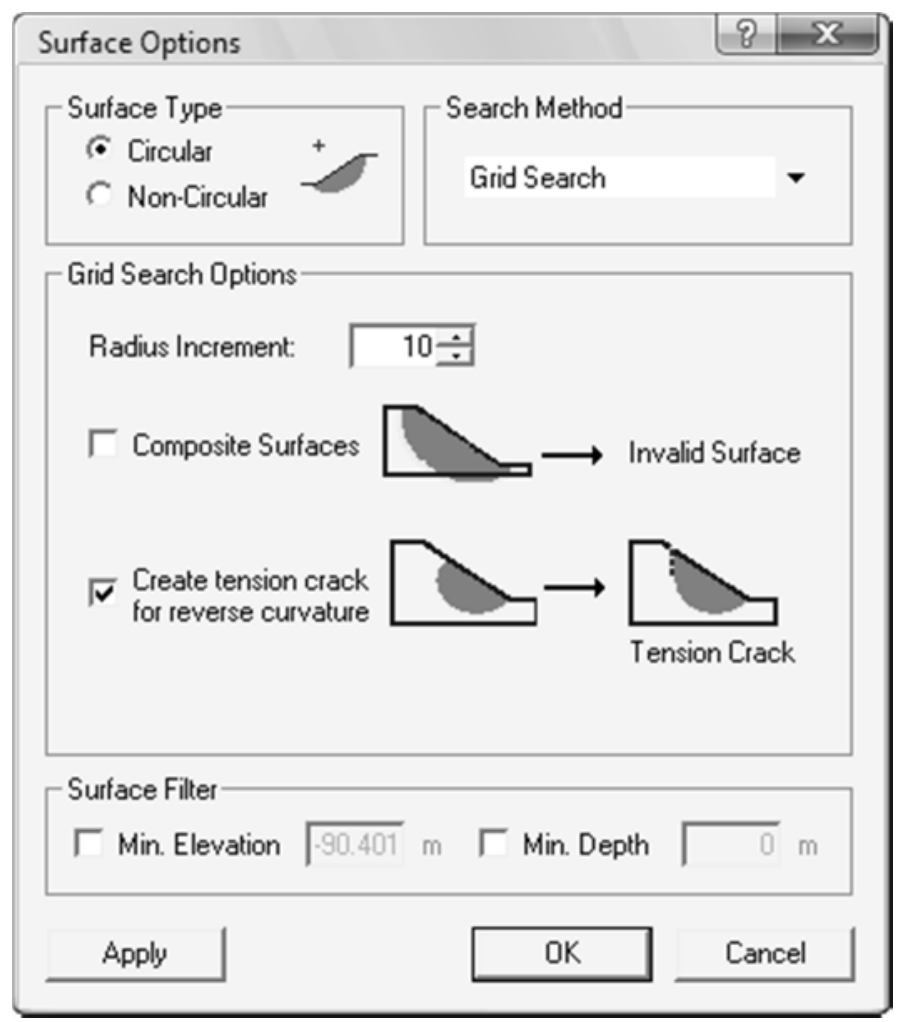

Gambar 15. Surface Options

Selanjutnya klik Auto Grid seperti gambar 15. untuk membuat grid yang memuat kemungkinan pusat gelincir. Jika dipilih Auto Grid maka Rocscience Slide akan membuat sebuah kota dengan kemungkinan bidang longsoran. Metode ini adalah metode paling lengkap dan efektif. Sebenarnya ada metode lain yang konvensional yaitu dengan menggambar sendiri kemungkinan busur 
lingkarannya. Jumlah kemungkinan pusat gelincir pada kota tersebut bisa diatur dengan memilih Grid Spacing.

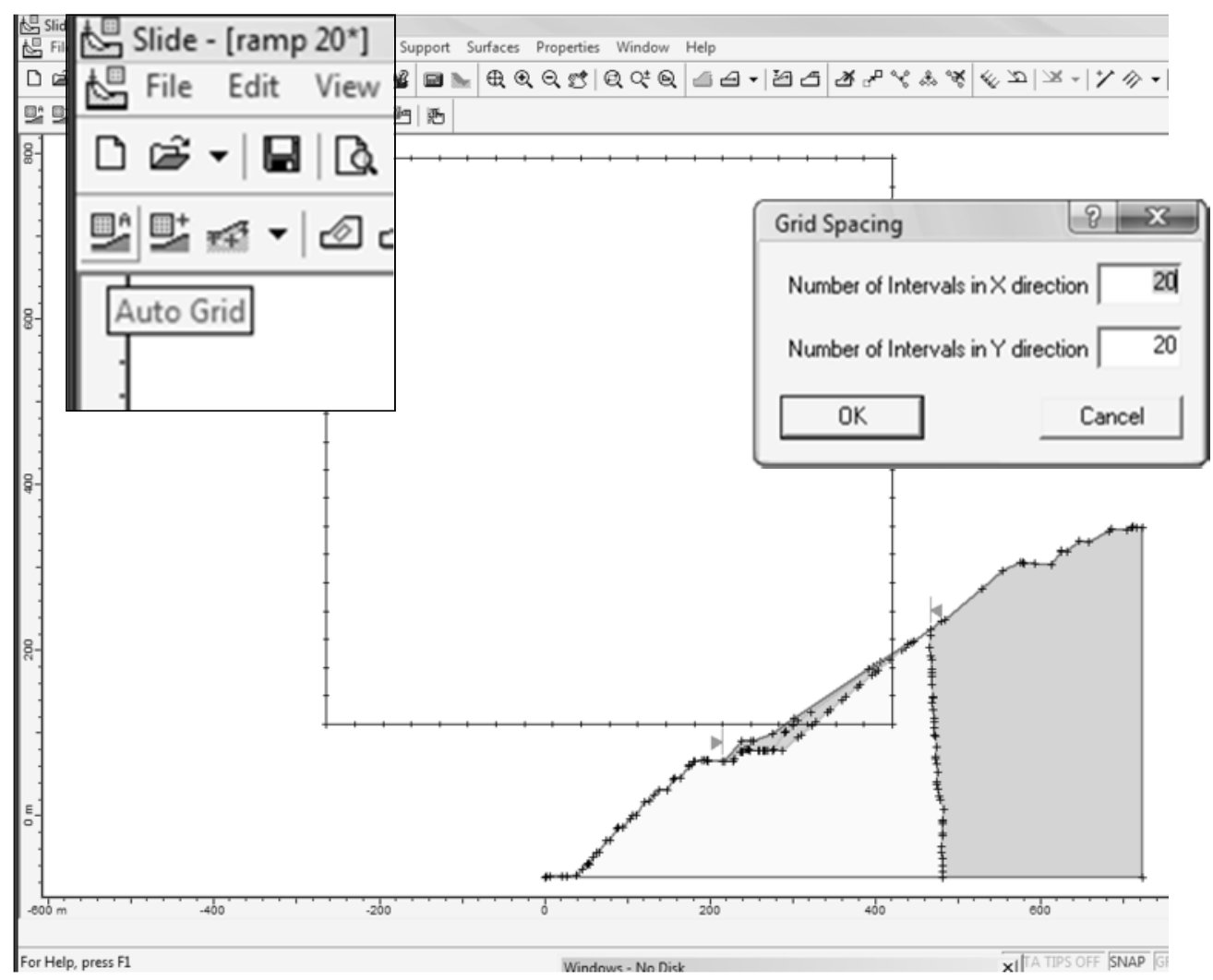

Gambar 16. Pengaturan dan tampilan setelah dibuat grid

\section{Running/kalkulasi}

Langkah terakhir dalam Rocscience adalah memulai perinta running. Caranya adalah menekan toolbar seperti pada gambar 3.23 kemudian Rocscience Slide akan melakukan perhitungan seperti pada gambar 3.24. Proses perhitungan tersebut memerlukan waktu beberapa menit (tergantung kecepatan bekerja komputer).

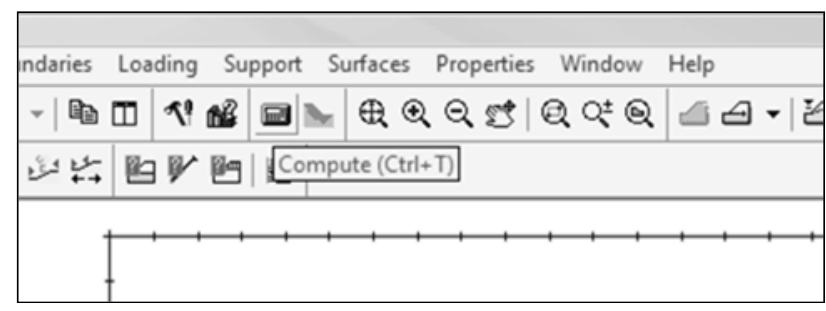

Gambar 17. Perintah untuk running 


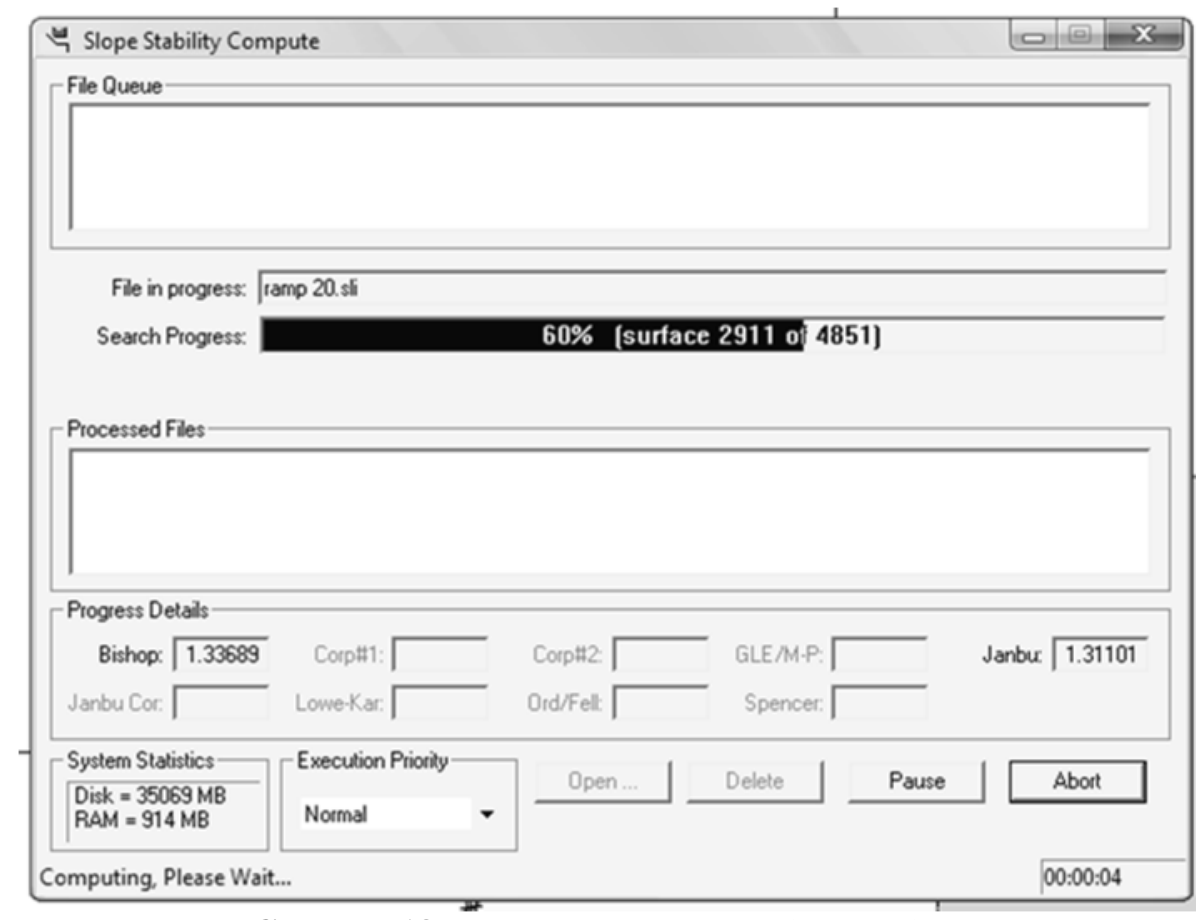

Gambar 18. Proses running Rocscience Slide

Top up menu Slope Stability Compute akan otomatis tertutup setelah proses perhitungan mencapai $100 \%$. Selanjutnya adalah melakukan interpretasi nilai $F O S$ dengan Rocscience Slide Interpret dengan perintah seperti pada gambar berikut :

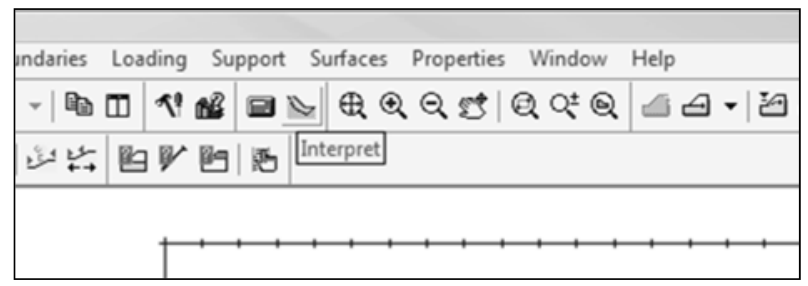

Gambar 19. Perintah untuk membuka Rocscience Slide Interpret

\section{Interpretasi nilai $\mathrm{FoS}$}

Rocscience Slide Interpret adalah software komplemen Slide yang berfungsi untuk melakukan interpretasi nilai $F o S$ hasil kalkulasi dengan Rocscience Slide. Ketika pertama kali dibuka dari file Rocscience Slide yang sedang dikerjakan maka Rocscience Slide Interpret akan menunjukkan nilai $F o S$ terkecil. 


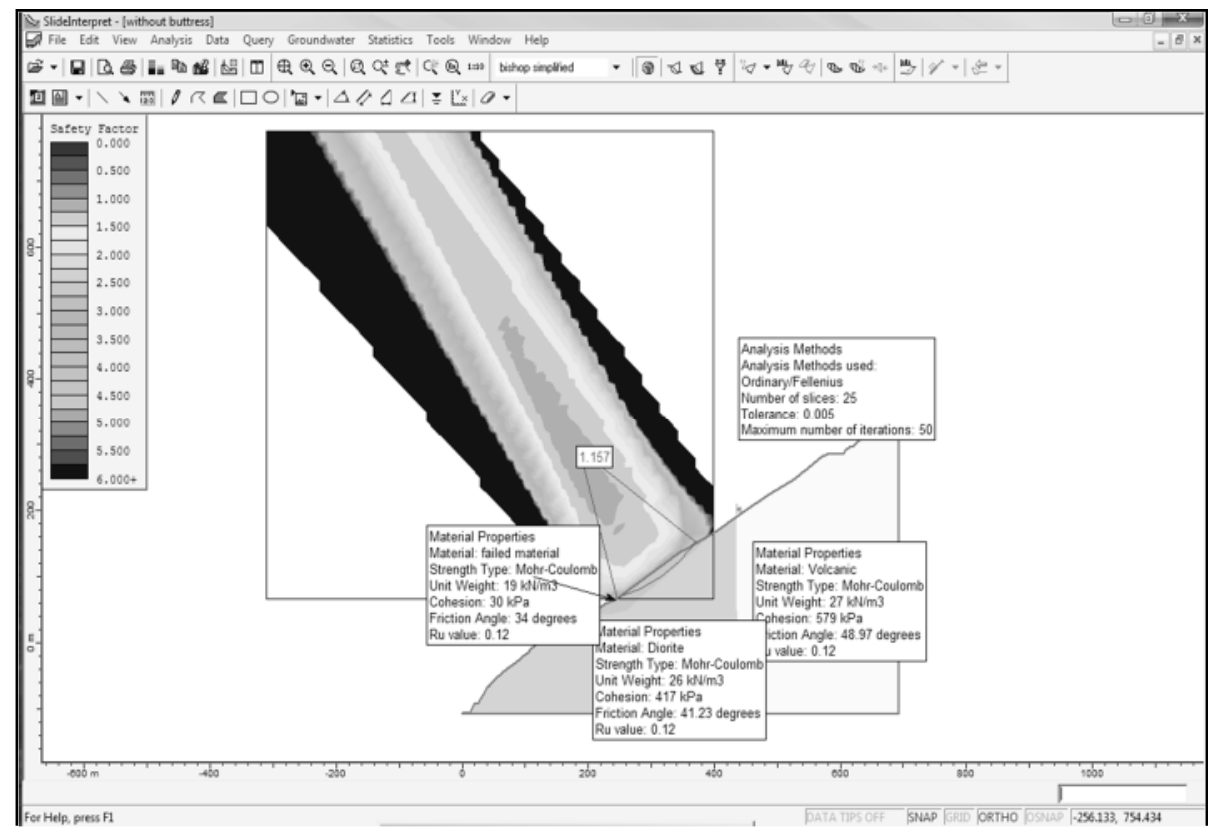

Gambar 20. Tampilan Rocscience Slide Interpret

Pada gambar terlihat di dalam kotak di atas lereng terdapa warna. Setiap warna menunjukkan nilai skala $F o S$ tertentu sesuai dengan petunjuk di bagian kiri. Nilai $F O S$ pada semua kemungkinan pusat gelincir yang terdapat pada skala warna terebut dapat diketahui. Dari gambar di atas juga terlihat pada failed material terdapat bentuk busur lingkaran. Busur tersebut akan berubah jika dipilih pusat gelincir yang berbeda. Nilai $F o S$ pada semua kemungkinan lokasi pusat gelincir tersebut dapat disajikan dalam bentuk grafik seperti pada gambar.

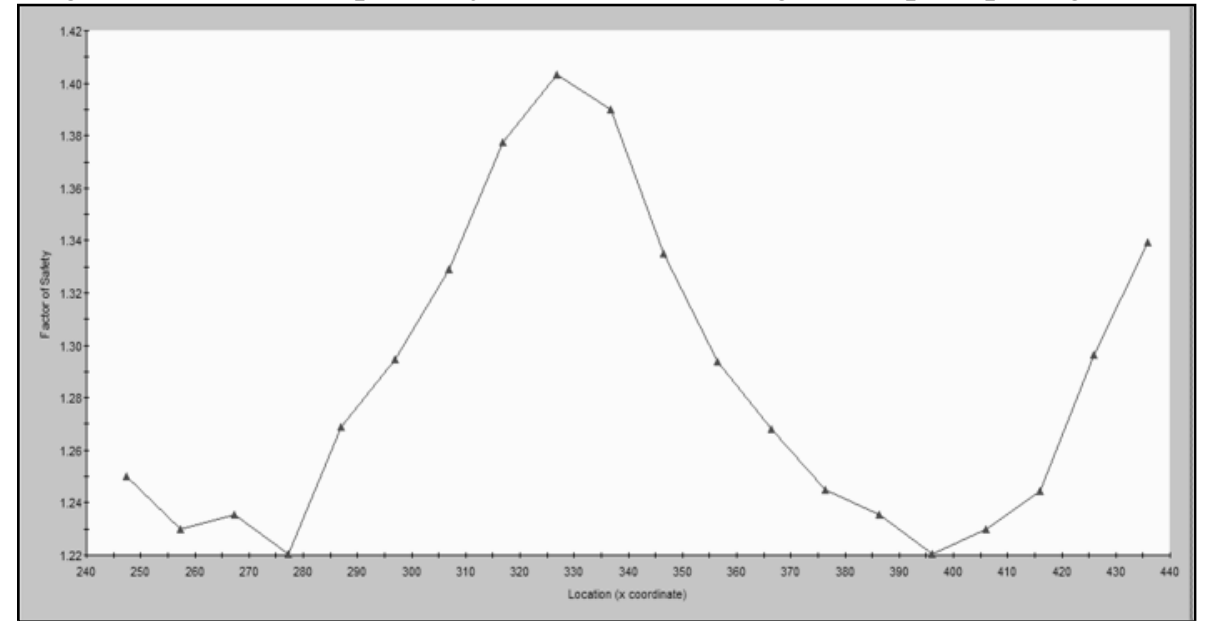

Gambar 21. Grafik nilai FoSberdasarkan koordinat pusat gelincir

Pada gambar 22. terlihat interpretasi hasil analisis kestabilang lereng lengkap dengan bidang gelincir berbentuk busur lingkaran, pusat gelincir disertai jari-jari, dan nilai $F o S$. Rocscience Slide Interpret juga dapat menunjukkan diagram gaya yang bekerja sesuai dengan karakteristik material dan geometri yang dibuat. Diagram tersebut dapat dilihat pada gambar 21. Data gaya yang bekerja tersebut juga dapat diinterprtasikan sebagai sebagai data numerik. 


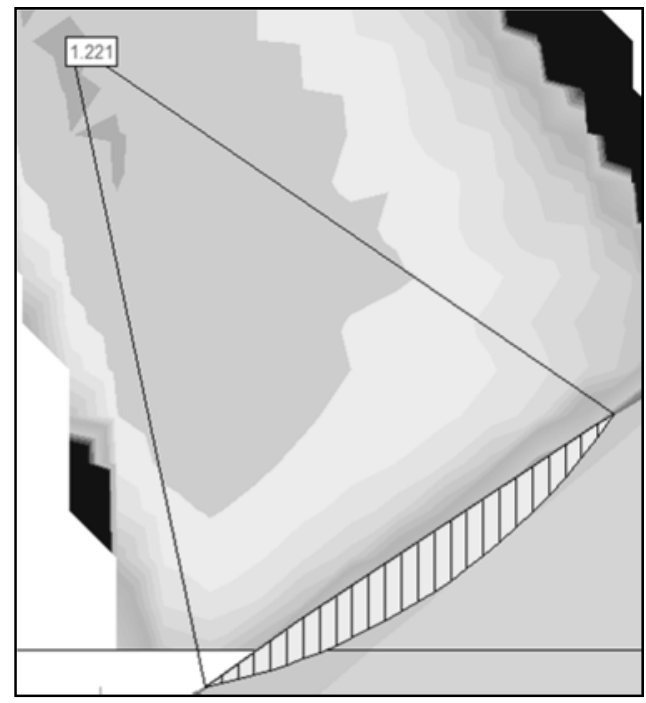

Gambar 22. Interpetasi hasil analisis kestabilan lereng

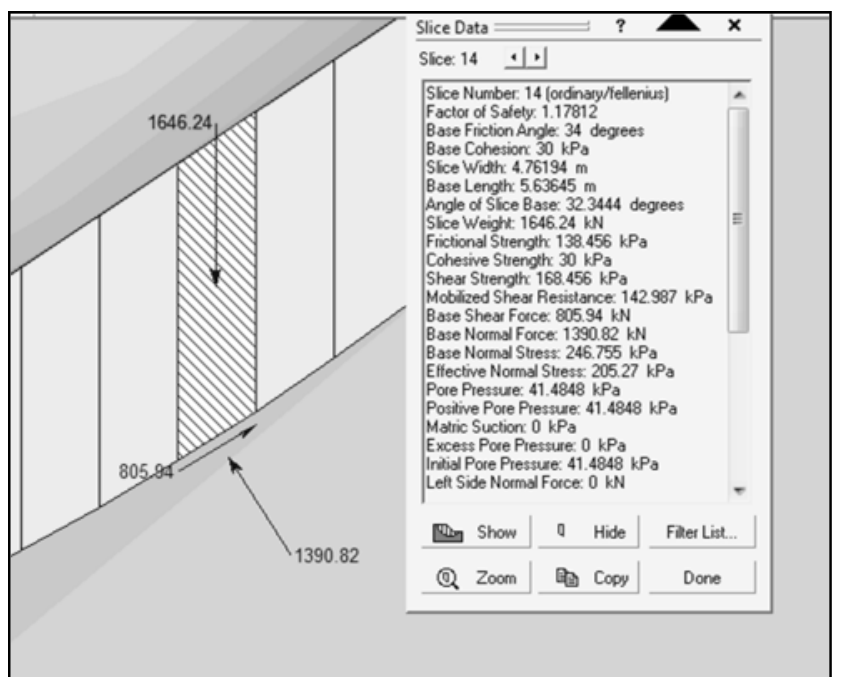

Gambar 23. Diagram gaya yang bekerja pada sebuah slice dengan metode Fellenius

Pendekatan yang digunakan menganggap bahwa keruntuhan lereng akan terjadi pada titik sepanjang permukaan runtuh yang diasumsikan maupaun diketahui, dan bentuk bidang longsor dalam dua dimensi.

Lereng yang terdiri dari tanah dan batuan dibagi menjadi 3 section di bandingkan pada saat sebelum konstruksi dan sesudah konstruksi dengan variable beban $0 \mathrm{t} / \mathrm{m} 2,2 \mathrm{t} / \mathrm{m} 2,5 \mathrm{t} / \mathrm{m} 2,10 \mathrm{t} / \mathrm{m} 2,20 \mathrm{t} / \mathrm{m} 2$, dan $40 \mathrm{t} / \mathrm{m} 2$ dan pada kondisi kondisi kenyang air (fully saturated) dan kondisi kering (dry). Untuk pembebanan di atas lereng dilakukan analisis untuk mengetahui jarak aman pembebanan dari crest lereng dengan mencoba membandingkan nilai FoS yang didapat pada apabila beban diletakkan pada jarak $3 \mathrm{~m}, 5 \mathrm{~m}$, dan $8 \mathrm{~m}$.

Metode analisis yang digunakan adalah metode Bishop Simplified dan Fellenius (Ordinary). Dalam analisisnya Fellenius mengabaikan keseirnbangan gaya di kedua sisi pias dan massa tanah yang diperkirakan akan runtuh sebagai satu kesatuan, metode ini merupakan metode dengan prosedur paling sederhana 
serta sebagai dasar sernua metode selanjutnya. Sedangkan metode Bishopmeniadakan sernua gaya geser antar irisan, narnun keseirnbangan gaya horisontal diperhitungkan secara keseluruhan.

Setiap section mempunyai geometri yang berbeda dan spesifik sehingga nilai FoS untuk nilai variabel yang sama terhadap section yang berbeda juga akan berbeda. Oleh karena itu dilakukan analisis terhadap tiga section yang dianggap bisa mewakili lereng sehingga akan diperoleh hasil analisis yang komprehensif.

Hasil kalkulasi nilai FoS adalah nilai FoS overall, yaitu yang bidang gelincirnya melewati daerah yang terbebani, agar pengaruh beban dapat terlihat dari hasil nilai FoSnya.

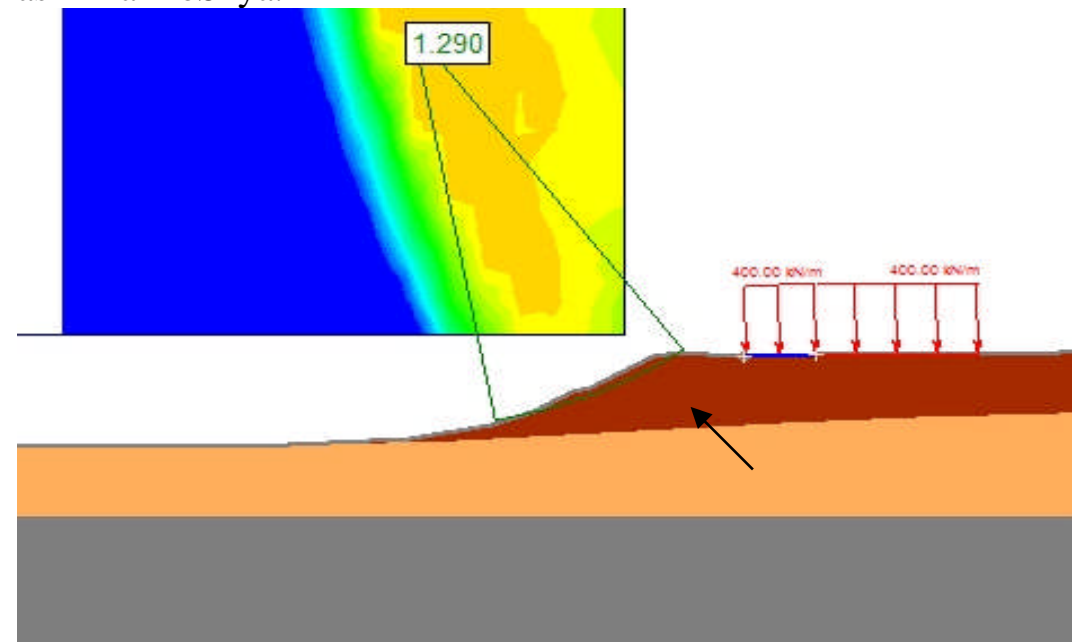

Gambar 24. Bidang gelincir section 1 dengan jarak dari crest lereng $5 \mathrm{~m}$ dan beban $400 \mathrm{kN} / \mathrm{m}$ (Bishop-Dry)

\section{Section 1}

Analisis yang dilakukan dimulai dari section 1. Nilai FoS untuk section 1 dengan metode Fellenius dan Bishop dapat dilihat pada tabel 4.1 dan tabel 4.2 dan grafik perbanndingan nilai FoS pada section dapat dilihat pada gambar 4.2. Dari analisis pada section 1 diperoleh trend semakin besar

Nilai $F o S$ dalam kondisi dry selalu lebih besar daripada kondisi wet. Perbedaan nilai $F o S$ antara kedua kondisi tersebut disebabkan oleh pengaruh tekanan air pori sebesar $12 \%$ berdasarkan nilai $R u=0.12$.

Tabel 1. Nilai FoS untuk section 1 dalam keadaan kering

\begin{tabular}{|c|c|c|c|c|c|c|}
\hline \multirow{3}{*}{ 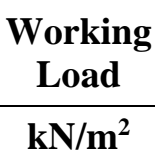 } & \multirow{2}{*}{\multicolumn{3}{|c|}{$\begin{array}{c}\text { FoS (dry) } \\
\text { Bishop }\end{array}$}} & \multirow{2}{*}{\multicolumn{3}{|c|}{$\begin{array}{c}\text { FoS (dry) } \\
\text { Fellenius (Ordinary) }\end{array}$}} \\
\hline & & & & & & \\
\hline & off set $\mathbf{3 m}$ & off set $5 \mathrm{~m}$ & off set $8 \mathrm{~m}$ & off set $3 \mathrm{~m}$ & off set $5 \mathrm{~m}$ & off set $8 \mathrm{~m}$ \\
\hline $\mathbf{0}$ & 1,482 & 1,482 & 1,482 & 1,437 & 1,437 & 1,437 \\
\hline 20 & 1,468 & 1,482 & 1,482 & 1,437 & 1,437 & 1,437 \\
\hline 50 & 1,424 & 1,482 & 1,482 & 1,388 & 1,437 & 1,437 \\
\hline 100 & 1,339 & 1,482 & 1,482 & 1,28 & 1,437 & 1,437 \\
\hline 200 & 1,194 & 1,367 & 1,482 & 1,012 & 1,193 & 1,437 \\
\hline 400 & 0,996 & 1,11 & 1,437 & 0,782 & 0,886 & 1,05 \\
\hline
\end{tabular}


Tabel 2. Nilai FoS untuk section 1 dalam keadaan basah.

\begin{tabular}{|c|c|c|c|c|c|c|}
\hline \multirow{2}{*}{$\begin{array}{c}\text { Working } \\
\text { Load }\end{array}$} & \multicolumn{3}{|c|}{ FoS (wet) } & \multicolumn{3}{|c|}{ FoS (wet) } \\
\hline & \multicolumn{3}{|c|}{ Bishop } & \multicolumn{3}{|c|}{ Fellenius (Ordinary) } \\
\hline $\mathrm{kN} / \mathrm{m}^{2}$ & off set $3 \mathrm{~m}$ & off set $5 \mathrm{~m}$ & off set $8 \mathrm{~m}$ & off set $3 \mathrm{~m}$ & off set $5 \mathrm{~m}$ & off set $8 \mathrm{~m}$ \\
\hline 0 & 1,285 & 1,285 & 1,285 & 1,224 & 1,224 & 1,224 \\
\hline 20 & 1,273 & 1,285 & 1,285 & 1,224 & 1,224 & 1,224 \\
\hline 50 & 1,246 & 1,285 & 1,285 & 1,224 & 1,224 & 1,224 \\
\hline 100 & 1,187 & 1,285 & 1,285 & 1,122 & 1,224 & 1,224 \\
\hline 200 & 1,078 & 1,246 & 1,285 & 0,909 & 1,077 & 1,224 \\
\hline 400 & 0,926 & 1,031 & 1,285 & 0,697 & 0,815 & 0,967 \\
\hline
\end{tabular}

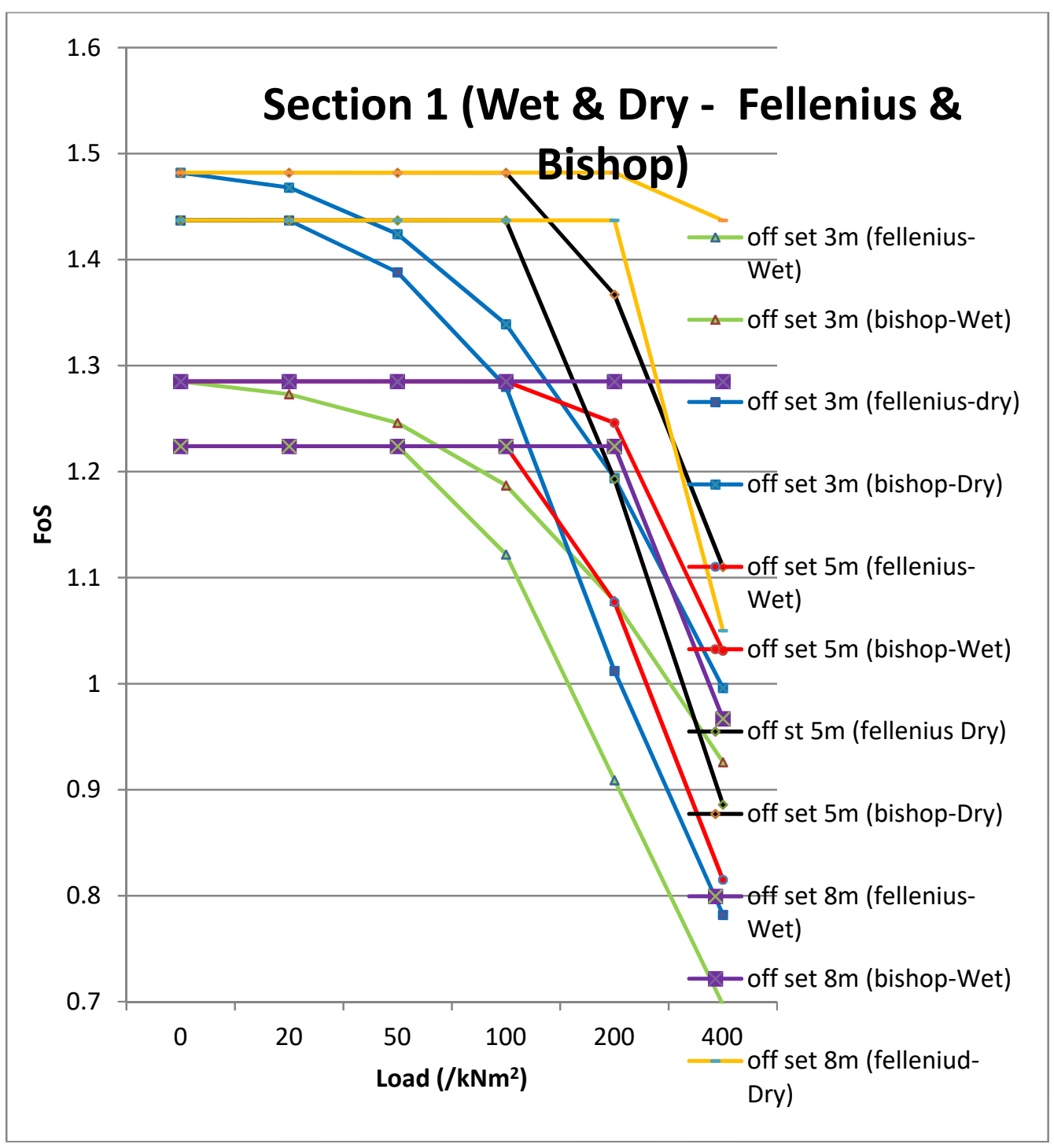

Gambar 25. Grafik nilai FoSsection 1 
Pada section 1 tanpa beban diperoleh nilai $F o S$ sebesar 1,285 (wet). Dengan penambahan beban $20 \mathrm{kN} / \mathrm{m}$ pada jarak 3 meter dari crest lereng diperoeh nilai $F o S$ sebesar 1.273. Perubahan nilai $F o S$ tersebut diakibatkan oleh penambahan driving force oleh beban bangunan dan jarak yang relatif dekat dengan crest lereng sehingga beban langsung menuju ke lereng dan mengurangi nilai FoS. Makabeban tersebut mempunyai pengaruh cukup besar terhadap nilai FoS.

\section{Section 2}

Nilai FoS section 2 menunjukkan trend yang menurun pada beban 100 $\mathrm{kN} / \mathrm{m}$ pada jarak $3 \mathrm{~m}$ dan pada jarak $5 \mathrm{~m}$ penurunan nilai $\mathrm{FoS}$ terjadi pada beban $200 \mathrm{kN} / \mathrm{m}$. Makin dekat jarak beban dari crest lereng makan nilai FoS makin kecil, dan makin besar beban diatas lereng maka nilai FoSnya makin kecil. Selain itu nilai pada $F o S$ kondisi $d r y$ juga lebih besar daripada kondisi wet.

Tabel 3. Nilai FoS untuk section 2 dalam keadaan kering

\begin{tabular}{|c|c|c|c|c|c|c|}
\hline \multirow{3}{*}{$\begin{array}{c}\begin{array}{c}\text { Working } \\
\text { Load }\end{array} \\
\mathrm{kN} / \mathbf{m}^{2} \\
\end{array}$} & \multicolumn{3}{|c|}{ FoS (dry) } & \multicolumn{3}{|c|}{ FoS (dry) } \\
\hline & \multicolumn{3}{|c|}{ Bishop } & \multicolumn{3}{|c|}{ Fellenius (Ordinary) } \\
\hline & off set $3 \mathrm{~m}$ & off set $5 \mathrm{~m}$ & off set $8 \mathrm{~m}$ & off set $3 \mathrm{~m}$ & off set $5 \mathrm{~m}$ & off set $8 \mathrm{~m}$ \\
\hline 0 & 1,399 & 1,399 & 1,399 & 1,368 & 1,368 & 1,368 \\
\hline 20 & 1,399 & 1,399 & 1,399 & 1,368 & 1,368 & 1,368 \\
\hline 50 & 1,399 & 1,399 & 1,386 & 1,36 & 1,368 & 1,342 \\
\hline 100 & 1,297 & 1,399 & 1,386 & 1,261 & 1,368 & 1,322 \\
\hline 200 & 1,172 & 1,366 & 1,361 & 1,119 & 1,267 & 1,304 \\
\hline 400 & 1,15 & 1,19 & 1,285 & 0,967 & 1,083 & 1,212 \\
\hline
\end{tabular}

Tabel 4. Nilai FoS untuk section 2 dalam keadaan basah

\begin{tabular}{|c|c|c|c|c|c|c|}
\hline \multirow{2}{*}{$\begin{array}{c}\text { Working } \\
\text { Load }\end{array}$} & \multicolumn{3}{|c|}{ FoS (wet) } & \multicolumn{3}{|c|}{ FoS (wet) } \\
\hline & \multicolumn{3}{|c|}{ Bishop } & \multicolumn{3}{|c|}{ Fellenius (Ordinary) } \\
\hline $\mathrm{kN} / \mathbf{m}^{2}$ & off set 3m & off set $5 \mathrm{~m}$ & off set $8 \mathrm{~m}$ & off set $3 \mathrm{~m}$ & off set $5 \mathrm{~m}$ & off set $8 \mathrm{~m}$ \\
\hline $\mathbf{0}$ & 1,208 & 1,208 & 1,208 & 1,178 & 1,178 & 1,178 \\
\hline 20 & 1,208 & 1,208 & 1,208 & 1,178 & 1,178 & 1,178 \\
\hline 50 & 1,208 & 1,208 & 1,204 & 1,166 & 1,178 & 1,16 \\
\hline 100 & 1,138 & 1,208 & 1,192 & 1,099 & 1,178 & 1,15 \\
\hline 200 & 1,101 & 1,17 & 1,165 & 1,07 & 1,108 & 1,117 \\
\hline 400 & 1,052 & 1,105 & 1,133 & 0,995 & 0,892 & 1,089 \\
\hline
\end{tabular}




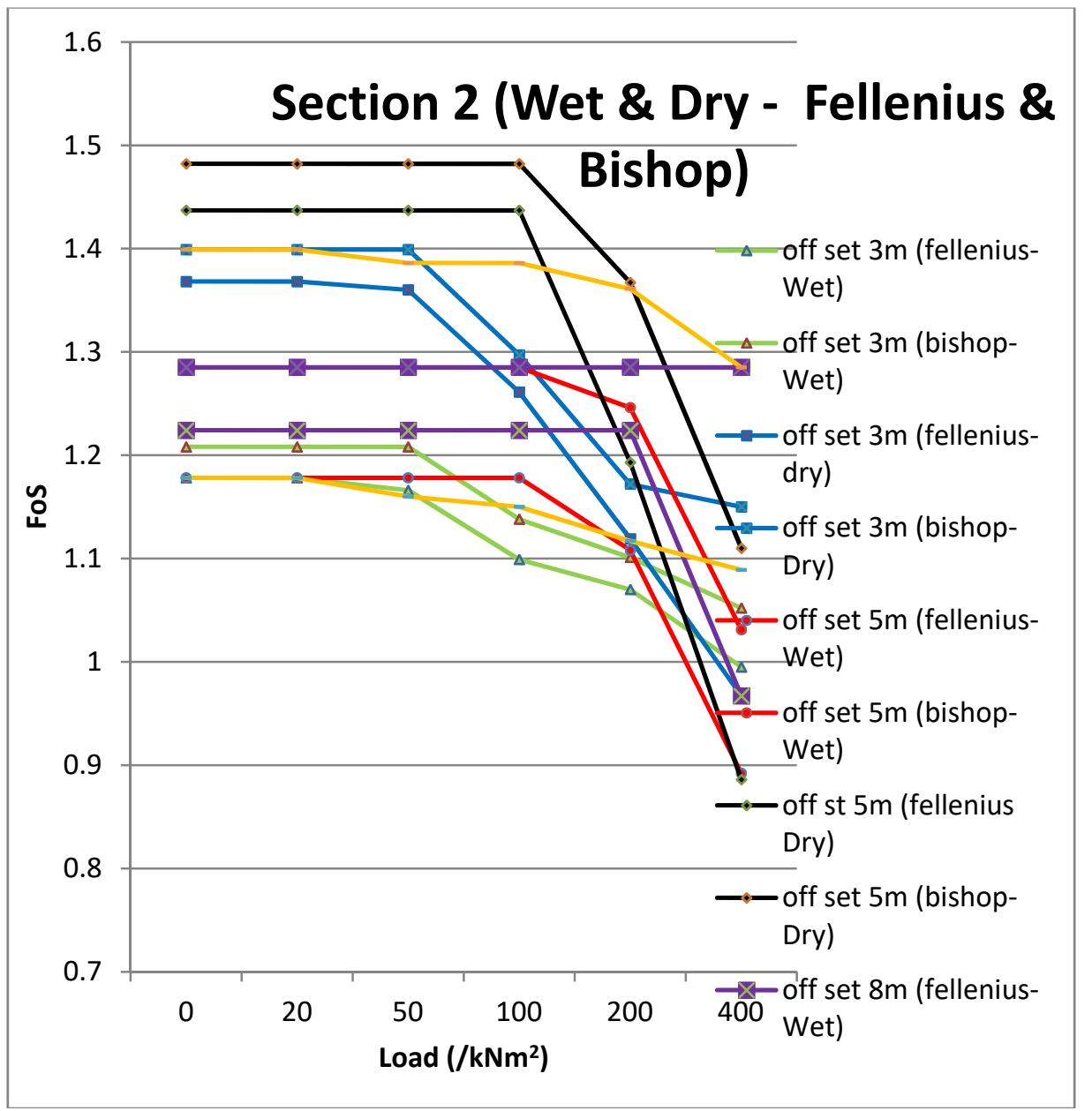

Gambar 26. Grafik nilai FoS section 2

\section{Section 3}

Secara umum grafik nilai $F o S$ pada section 3 sama dengan section 1 dengan trend penurunan mulai dari beban $20 \mathrm{kN} / \mathrm{m}$ pada jarak $3 \mathrm{~m}$ karena makin dekat jarak beban dari crest lereng maka nilai FoS makin kecil.. Selain itu perbedaan nilai $F o S$ untuk kondisi wet dan dry sama dengan dua section sebelumnya.

Tabel 5. Nilai FoS untuk section 3 dalam keadaan kering

\begin{tabular}{|c|c|c|c|c|c|c|}
\hline \multirow{2}{*}{$\begin{array}{c}\text { Working } \\
\text { Load }\end{array}$} & \multicolumn{3}{|c|}{ FoS (dry) } & \multicolumn{3}{c|}{ FoS (dry) } \\
\cline { 2 - 7 } kN/m & \multicolumn{3}{|c|}{ Bellenius (Ordinary) } \\
\hline $\mathbf{0}$ & 1,169 & 1,169 & 1,169 & 1,176 & 1,176 & 1,176 \\
\hline $\mathbf{2 0}$ & 1,139 & 1,156 & 1,165 & 1,132 & 1,151 & 1,159 \\
\hline $\mathbf{5 0}$ & 1,1 & 1,138 & 1,165 & 1,074 & 1,115 & 1,159 \\
\hline $\mathbf{1 0 0}$ & 1,048 & 1,11 & 1,165 & 0,996 & 1,06 & 1,159 \\
\hline $\mathbf{2 0 0}$ & 0,973 & 1,064 & 1,165 & 0,917 & 1,006 & 1,159 \\
\hline $\mathbf{4 0 0}$ & 0,881 & 0,993 & 1,16 & 0,834 & 0,933 & 1,159 \\
\hline
\end{tabular}


Tabel 6. Nilai FoS untuk section 3 dalam keadaan basah

\begin{tabular}{|c|c|c|c|c|c|c|}
\hline \multirow{2}{*}{$\begin{array}{c}\text { Working } \\
\text { Load }\end{array}$} & \multicolumn{3}{|c|}{ FoS (wet) } & \multicolumn{3}{c|}{ FoS (wet) } \\
\cline { 2 - 7 } Bishop & \multicolumn{3}{c|}{ Fellenius (Ordinary) } \\
\hline $\mathbf{k N / \mathbf { m } ^ { 2 }}$ & off set 3m & off set 5m & off set 8m & off set 3m & off set 5m & off set 8m \\
\hline $\mathbf{0}$ & 0,997 & 0,997 & 0,997 & 1,003 & 1,003 & 1,003 \\
\hline $\mathbf{2 0}$ & 0,997 & 0,988 & 0,991 & 0,969 & 0,981 & 0,983 \\
\hline $\mathbf{5 0}$ & 0,951 & 0,976 & 0,991 & 0,925 & 0,951 & 0,983 \\
\hline $\mathbf{1 0 0}$ & 0,916 & 0,956 & 0,991 & 0,866 & 0,906 & 0,983 \\
\hline $\mathbf{2 0 0}$ & 0,863 & 0,924 & 0,991 & 0,863 & 0,867 & 0,983 \\
\hline $\mathbf{4 0 0}$ & 0,801 & 0,873 & 0,988 & 0,755 & 0,817 & 0,983 \\
\hline
\end{tabular}

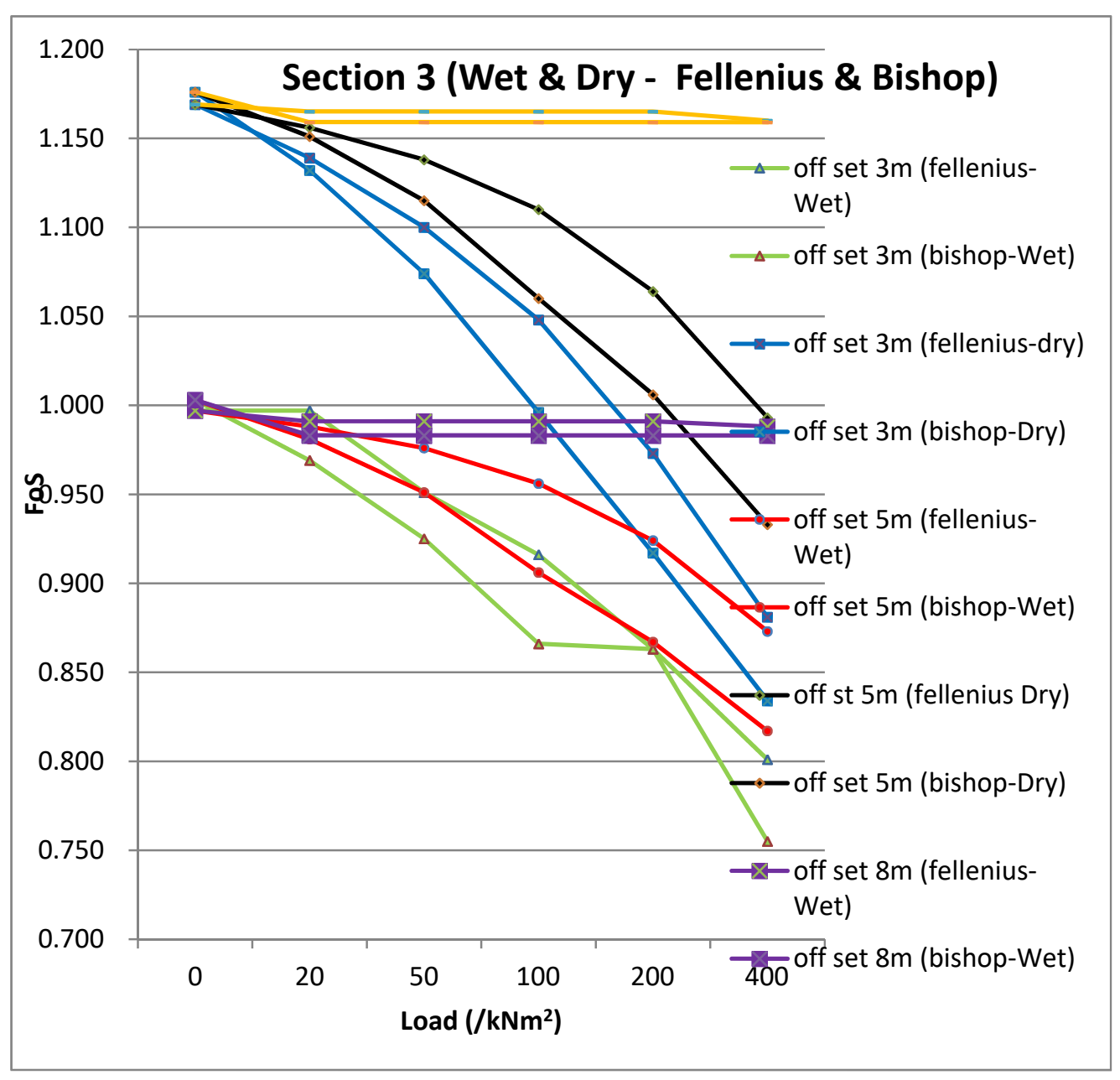

Gambar 27. Grafik nilai FoS section 3

\section{Perbandingan Nilai FoS Section 1, 2, dan 3}

Analisis pada tiap section menunjukkan trend yang relatif sama, menurun dengan bertambahnya beban dan semakin dekatnya jarak beban dari crest lereng. Pada section 2 penurunan nilai FoS terjadi pada jarak $3 \mathrm{~m}$ dengan beban $100 \mathrm{kN} / \mathrm{m}$ karena bentuk topografi pada section 2 membentuk timbunan yang dapat menahan beban sehingga pada saat pembebanan $20 \mathrm{kN} / \mathrm{m}$ dan $50 \mathrm{kN} / \mathrm{m}$ 
niali FoS di section 2 tidak terjadi penurunanyangsignifikan. Hasil FoS di Section 1 untuk semua variasi beban dan jarak dari crest lereng relatif paling besar dibandingkan section 2 dan 3 . Hal ini disebabkan karena sudut kemiringan lereng keseluruhan section 1 paling kecil (landai) dibandingkan section 2 dan 3.

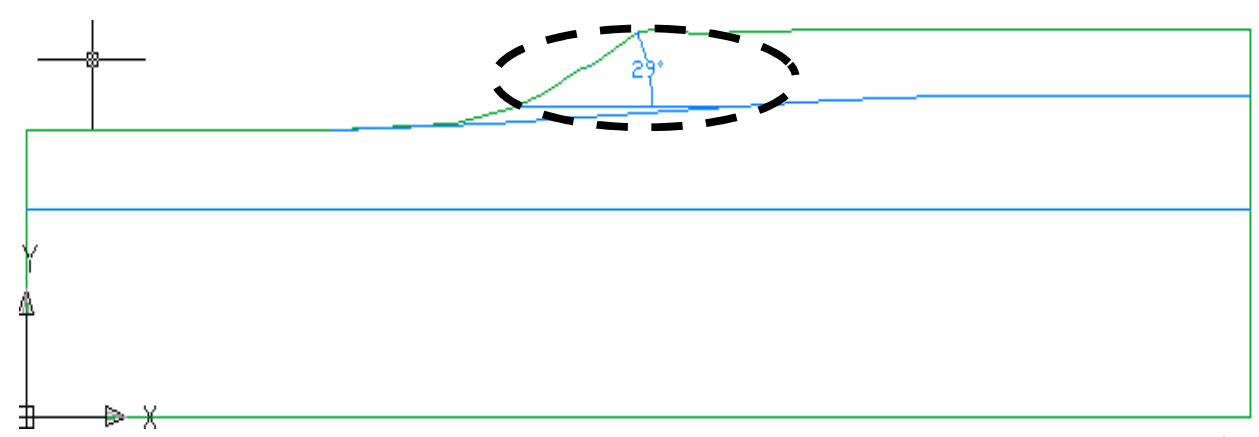

Gambar 28. Geometri lereng section 1 dengan sudut keseluruhan $29^{\circ}$

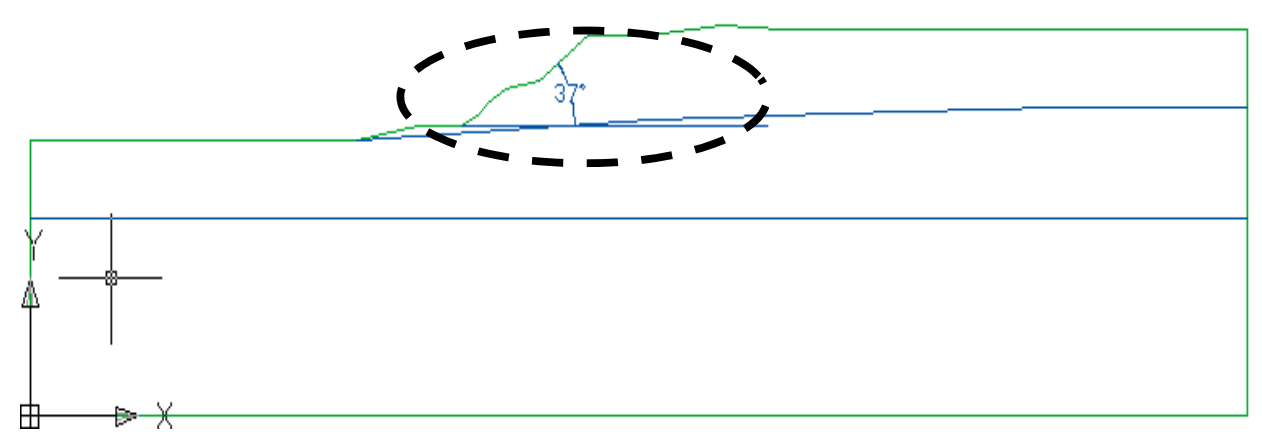

Gambar 29. Geometri lereng section 2 dengan sudut keseluruhan $37^{\circ}$

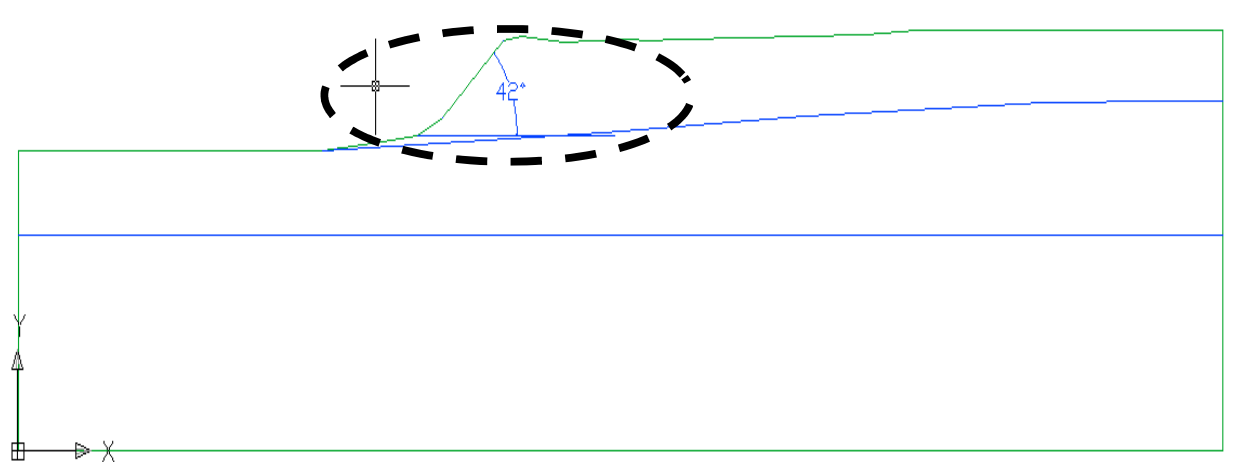

Gambar 30. Geometri lereng section 1 dengan sudut keseluruhan $42^{\circ}$

Nilai $F o S$ dari ketiga section yang dianalisis bervariasi, nilai standar FoS yang digunakan adalah 1,2. Pada section 3 nilai FoS tidak memenuhi syarat baik pada kondisi kering maupun kondisi jenuh air. Maka dari itu untuk meningkakan nilai FoS pada lereng ini terutama di section 3 sebaiknya dilakukan perbaikan lereng agar proses konstruksi bisa berjalan dan lereng tidak longsor. Dilakukan pembuatan horizontal drain untuk mengurangi air tanah agar kekuatan geser tanah lebih besar sehinga menghasilkan nilai FoS yang aman. 


\section{Analisis Pengaruh Sudut Keseluruhan Lereng terhadap Jarak Aman.}

Dari hasil analisis diatas, sudut kemiringan lereng juga berpengaruh terhadap jarak aman, semakin besar sudut lereng makan jarak aman yang didapat akan makin besar dari crest lereng. Hal ini disebabkan oleh gaya pendorong longsor makin besar pada lereng dengan sudut kemiringan semakin besar. Ilustrasinya sebagai berikut :

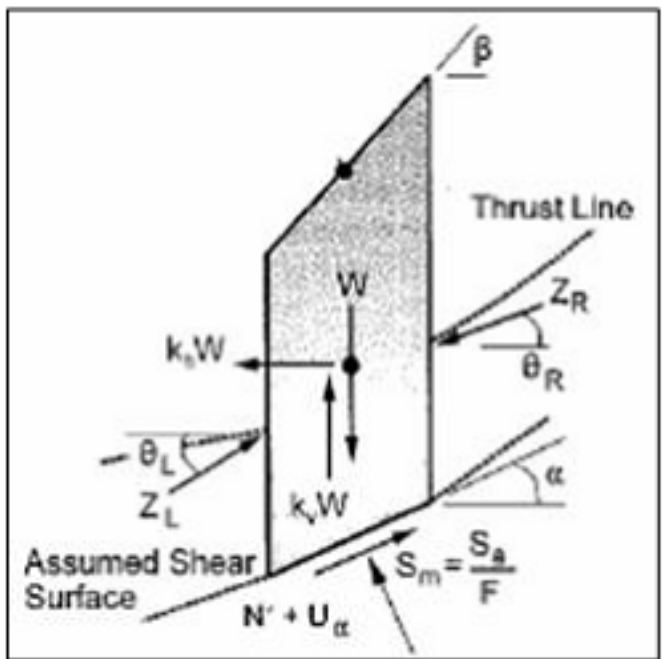

Gambar 31. Gaya-gaya yang bekerja pada pusat longsoran busur.

Pada gambar irisan diatas faktor kegempaan tidak diperhitungkan $(\mathrm{kh}=$ 0 dan $\mathrm{kv}=0$ ), maka faktor keamanannya menjadi :

$$
F \text { os }=\frac{\sum(C+N \tan \phi)}{\sum W \sin \alpha}
$$

Dimana :

$\mathrm{c}=$ kohesi material

$\mathrm{N}=$ Gaya normal

$\mathrm{W}=$ Berat dari slice (irisan

$\emptyset=$ sudut geser dalam material

$\alpha=$ kemiringan dari dasar irisan $\left(0^{\circ}<\alpha<90^{\circ}\right)$

Dapat dilihat berdasarkan persamaan diatas, bahwa dengan naiknya nilai sudut $\alpha$, maka gaya dorong (penggerak) dari material akan meningkat. Sedangkan sudut $\alpha$ sebanding dengan sudut keseluruhan, sehingga dengan bertambanhnya sudut lereng makan $\alpha$ akan semakin besar.

Penelitian para ahli geoteknik (Barton, 1981 : Singh, 1986 : Hawley, 1986) menyatakan makin kecil kemiringan dan ketinggian lereng makan lereng tersebut akan semakin stabil, sebaliknya makin besar kemiringan dan ketinggian lereng maka lereng semakin tidak stabil, sehingga jarak aman minimum harus semakin besar pula.

Jarak aman yang didapat dari hasil analisis daiatas adalah jarak $5-8 \mathrm{~m}$ karena pada jarak 3 m nilai FoS semakin menurun, beban diatas lereng dengan jarak $3 \mathrm{~m}$ sangat berpengaruh pada nilai FoS, karena ada beban di ats lereng 
maka gaya pendorongnya (driving forces) makin besar sehingga nilai FoSnya menurun.

Analisis Pengaruh Air Tanah pada Lereng terhadap Jarak Aman dan nilai Faktor Keamanan.

Dari hasil analisis diatas, pada kondisi kering dan jenuh air (fully saturated) juga memperlihatkan hasil yang berbeda, dapat dilihat pada gambar

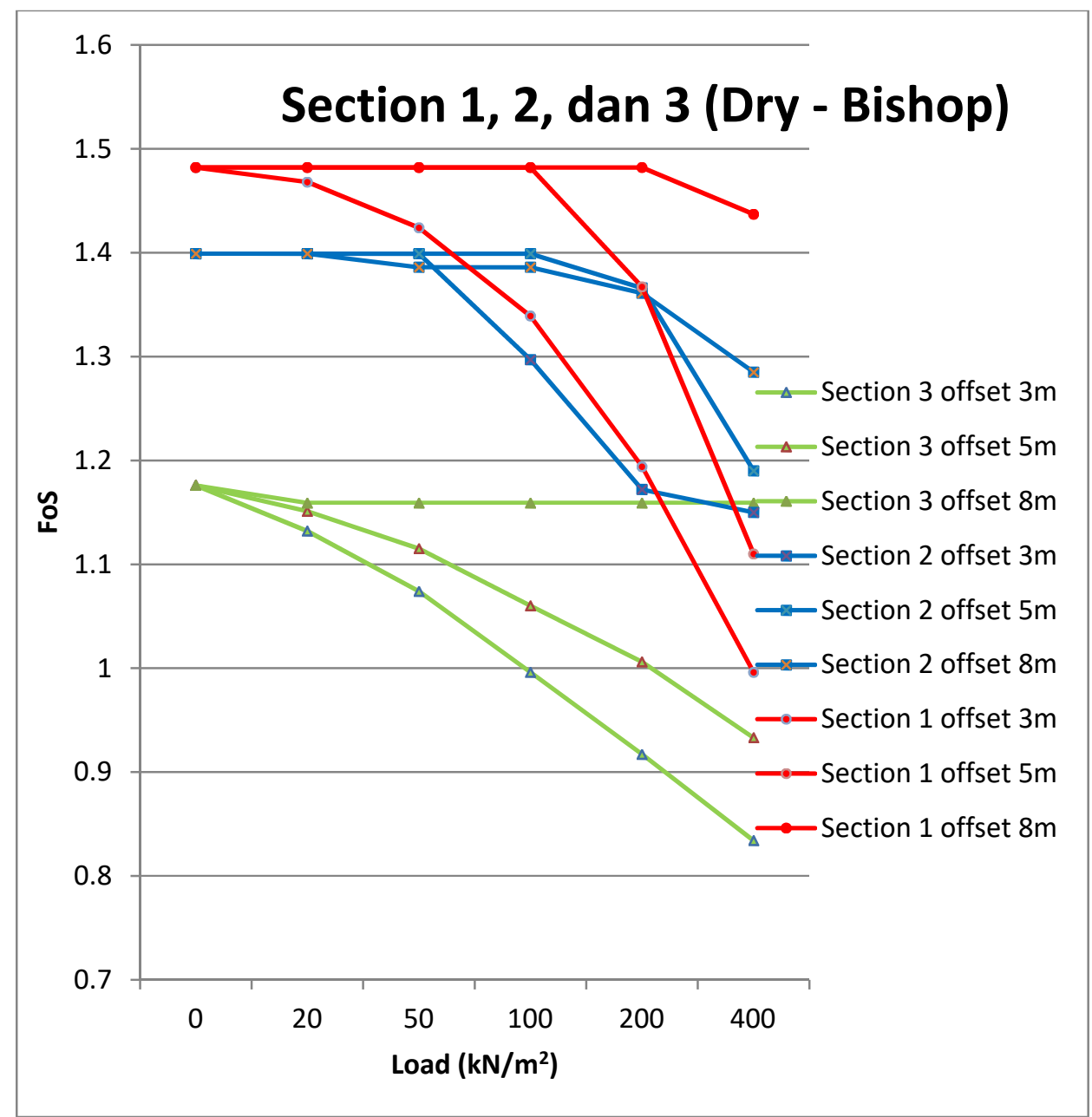

Gambar 32. Grafik nilai FoS section1,2,dan 3 pada kondisi kering

Pada grafik diatas dapat diasumsikan pada musim penghujan, maka grafik tersebut dapat diambil sebagai acuan. 


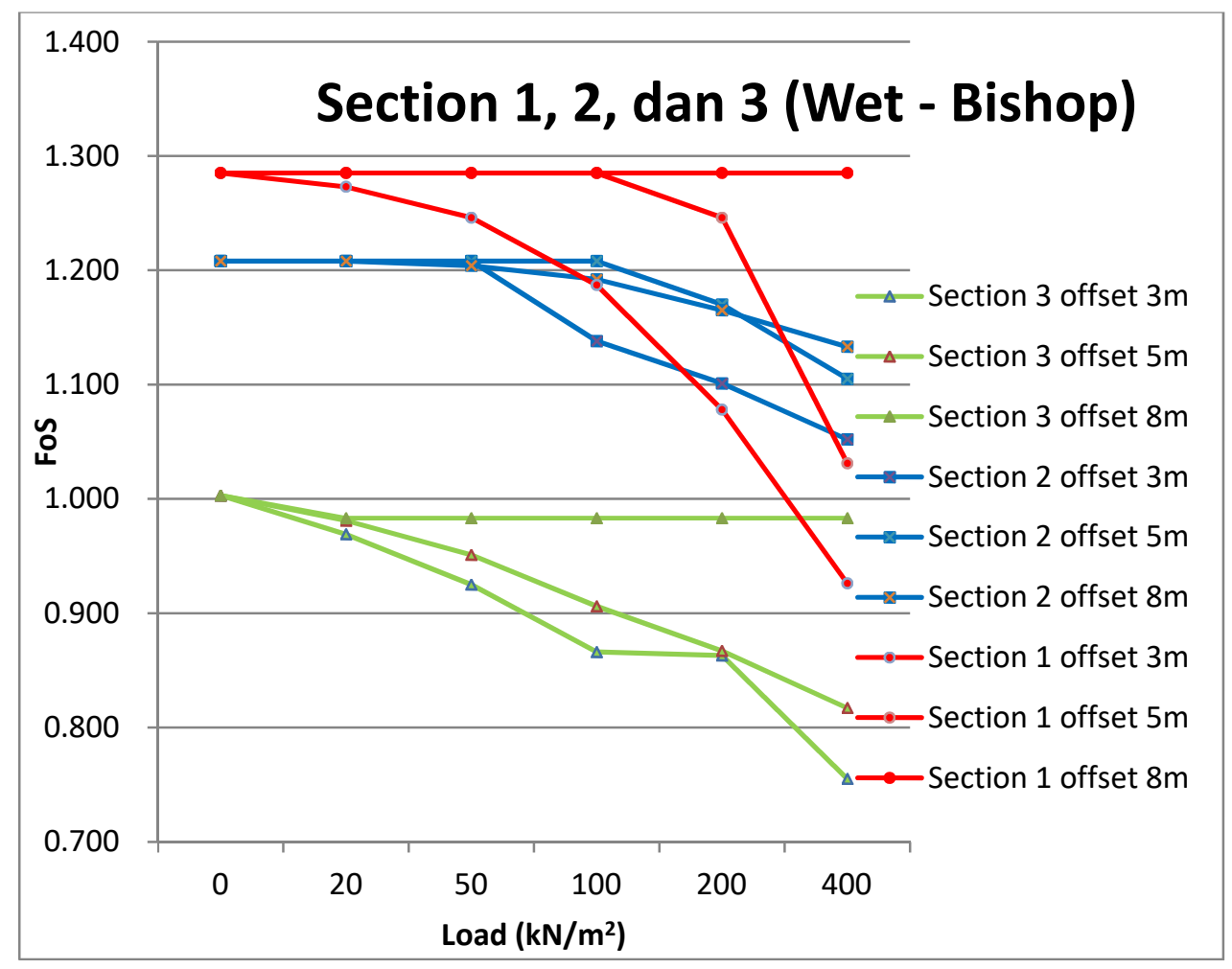

Gambar 33. Grafik nilai FoS section1,2,dan 3 pada kondisi wet

Pada grafik diatas dapat diasumsikan pada musim penghujan, maka grafik tersebut dapat diambil sebagai acuan.

Air hujan akan menyebabkan terjadinya erosi dan penambahan beban pada lereng. Erosi akan menyebabkan perubahan geometri lereng terutama sudut lereng keseluruhan akibat tingkat pelapukan yang tinggi didaerah curah hujan tinngi yang curam karena sudut lereng keseluruhan lebih besar. Kecepatan pengikisan yang tinggi dan menyebabkan pengikisan akan lebih intensif dibandingkan daerah landai. Oleh karena itu perlu diperhatikan pada musim penghujan perubahan sudut lereng keseluruhan.

Kondisi jenuh air akan mempengaruhi besarnya tergangan normal pada permukaan gese. Ilustrasinya sebagai berikut :

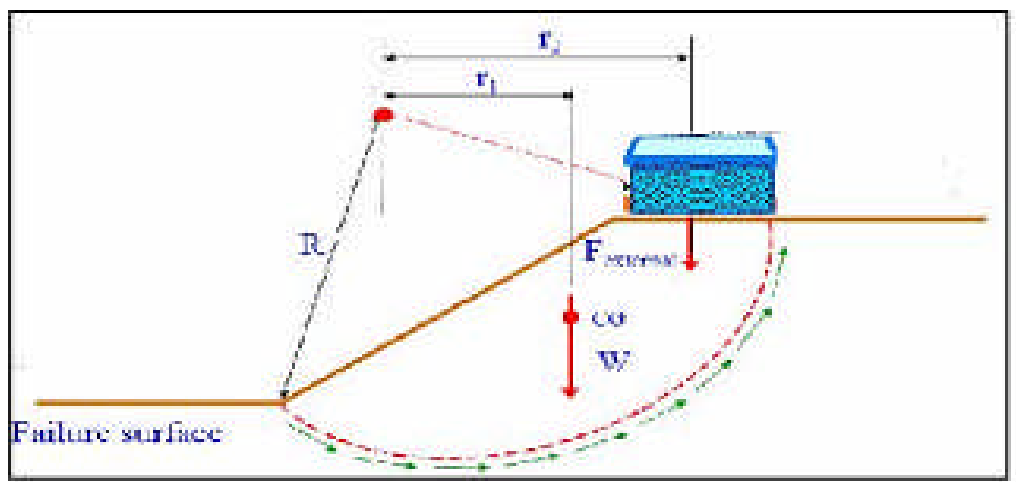

Gambar 34. Pengaruh kuat geser terhadap Faktor Keamanan pada longsoran busur. 


$$
F S=\frac{\tau_{\text {Max }} \cdot L \cdot R}{W \cdot r_{1}+F_{\text {Entarnal }} \cdot r_{2}} .
$$

Asumsi : Bidang gelincirnya sepanjang $\mathrm{L}$ dan $\boldsymbol{\tau}$ max adalah konstan.

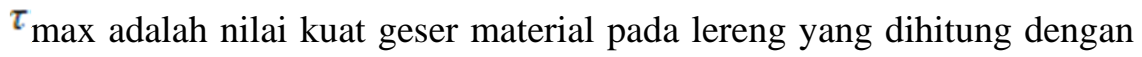
criteria Mohr-Coulomb sebagai berikut :

$$
\tau=C+\sigma_{n} \tan \phi
$$

Akibat adanya permukaan air, makan akan timbul tekanan air pori (tegangan air pori) sebesar $\mathrm{u}$, gaya normal $\sigma_{\mathrm{n}}$ yang bekerja pada dengan arah tegak lurus akan berkurang menjadi tegangan efektif (effective stress) sebesar ( $\left.\sigma_{n-u}\right)$, maka persamaan diatas menjadi :

$$
\tau=c+(\sigma-u) \operatorname{tg} \varphi
$$

Dari persamaan kekuatan geser tanah atau batuan diatas, jelas terlihat bahwa semakin besar nilai tegangan pori yang diakibatkan oleh adanya permukaan air, akan memperkecil harga kekuatan geser tanah atau batuan. Jadi dapat dikatakan bahwa suatu lereng yang kenyang air atau jenuh maka lereng tersebut kurang mantap pada geometri lereng yang sama.

Pengaruh perubahan tegangan geser terhadap jarak aman dari crest ke beban terlihat pada persamaan di atas . Berdasarkan persamaan tersebut terlihat nilai $\tau$ sebanding dengan nilai $\mathrm{r}_{2}$ yang merupakan jarak antara beban dengan pusat longsoran, sedangkan jarak aman yang dicari sebanding dengan nilai $\mathbf{r}_{2}$

Disamping itu, kondisi lereng yang jenuh air dapat menambah beban pada bidang longsor sehingga akan meningkatkan gaya penggerak akibat total berat $(\mathrm{W})$ yang meningkat dan menurunkan nilai FoS.

\section{Kesimpulan}

Dari hasil analisis dapat disimpulkan :

1) Semakin besar beban yang ada pada crest lereng maka maka nilai $F o S$ semakin kecil. Makin besar beban maka driving forces yang ada pada lereng semakin besar sehingga nilai FoS semakin kecil.

2) Nilai $F o S$ untuk semua metode, section, dan lebar ramp lebih besar dalam kondisi kering daripada basah.Oleh karena itu air sangat berpengaruh terhadap kestabilan lereng. Di section 1, 2, dan 3 air akan menurunkan nilai FoS sekitar $12 \%$ (sesuai dengan nilai $\mathrm{Ru}$ )

3) Semakin besar jarak beban dari crest lereng maka maka nilai $F o S$ semakin besar. Semakin dekat jarak dari crest lereng makan pengaruh dari beban akan makin besar, sehingga nilai FoS makin kecil. Pada jarak 3m dari crest lereng penurunan nilai FoS sangat sifnifikan, pada section 1 dan 2 masih didapatkan niali FoS yang aman dengan beban $50 \mathrm{kN} / \mathrm{m}$, karena beban yang dapat diterima terlalu kecil, maka utuk jarak aman yang dapat dilakukan adalah jarak $5 \mathrm{~m}$ dn $8 \mathrm{~m}$

4) Semakin kecil sudut lereng keseluruhan (landai) maka nilai FoS semakin besar. 


\section{Daftar Pustaka}

1) Almanera, Raimundo dan Nasution, Yuda., Rock Slope Stability Concepts. (Presentasi Stabilitas Lereng ) PT. Newmont Nusa Tenggara. 2007

2) Das.B.M.. Mekanika Tanah (Prinsip-prinsip Rekayasa Geoteknis).Jakarta. Erlangga,Terjemahan, 1988.

3) Darma, Edifrizal.. Beban Ekstenal Pada Struktur. Bahan Ajar Statika. Jakarta.2009.

4) Maulana, H. Dan Inayatillah, A. Tutorial Rocscience Slide V. 5.0 Untuk Kstabilan Lereng. Jakarta, 2010 